Silvia Lucena Lage

INFLUÊNCIA DO RECONHECIMENTO DA FLAGELINA EXTRA E INTRACELULAR NO PROCESSO DE PIROPTOSE EM MACRÓFAGOS

Dissertação apresentada ao Programa de Pós-Graduação em Imunologia do Instituto de Ciências Biomédicas da Universidade de São Paulo para obtenção do Título de Mestre em Ciências 
Silvia Lucena Lage

\title{
INFLUÊNCIA DO RECONHECIMENTO DA FLAGELINA EXTRA E INTRACELULAR NO PROCESSO DE PIROPTOSE EM MACRÓFAGOS
}

\author{
Dissertação apresentada ao Programa \\ de Pós-Graduação em Imunologia do \\ Instituto de Ciências Biomédicas da \\ Universidade de São Paulo para \\ obtenção do Título de Mestre em \\ Ciências
}

Área de concentração: Imunologia

Orientador(a): $\operatorname{Prf}^{a} D^{a}$ Karina

Ramalho Bortoluci 
DADOS DE CATALOGAÇÃO NA PUBLICAÇÃO (CIP)

Serviço de Biblioteca e Informação Biomédica do Instituto de Ciências Biomédicas da Universidade de São Paulo

reprodução não autorizada pelo autor

Lage, Silvia Lucena.

Influência do reconhecimento da flagelina extra e intracelular no processo de piroptose em macrófagos / Silvia Lucena Lage. -- São Paulo, 2011.

Orientador: Karina Ramalho Bortoluci.

Dissertação (Mestrado) - Universidade de São Paulo. Instituto de Ciências Biomédicas. Departamento de Imunologia. Área de concentração: Imunologia. Linha de pesquisa: Imunidade inata.

Versão do título para o inglês: Influence of extra and intracellular flagellin recognition in the regulation of macrophage pyroptosis.

Descritores: 1. Flagelina 2. Inflamassomas 3. Piroptose 4. Macrófagos 5. Caspase-1 6 Receptores de reconhecimento de padrões moleculares (PRRs) I. Bortoluci, Karina Ramalho II. Universidade de São Paulo. Instituto de Ciências Biomédicas. Programa de Pós-Graduação em Imunologia III. Título. 
Candidato(a):

Título da Dissertação:

Orientador(a):

\section{Silvia Lucena Lage.}

Influência do reconhecimento da flagelina extra e intracelular no processo de piroptose em macrófagos.

A Comissão Julgadora dos trabalhos de Defesa da Dissertação de Mestrado, em sessão pública realizada a ..$/$. ...

\section{( ) Aprovado(a) （ ) Reprovado(a)}

Examinador(a): Assinatura:

Nome:

Instituição:

Examinador(a): Assinatura:

Nome:

Instituição:

Presidente: Assinatura:

Nome:

Instituição: 


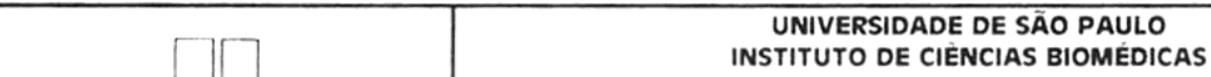

Cidade Universitária "Armando de Salles Oliveira"

Av. Prof. Lineu Prestes, 2415 - Cep. 05508-900 São Paulo, SP - Brasi Telefone:(55) (011) 3091.7733 - telefax : (55) (011)3091-7438 e-mail: cep@icb.usp.br

DeCl. CEEA.16.09

\section{DECLARAÇ Ã O}

Em adendo ao Certificado 109/07/CEEA, datado de 06.12.07. por solicitação da Profa. Dra. Karina Bastos, responsavel pelas linhas de Pesquisas, autorizo a inclusão da aluna SILvia LuCEna LAGe ao projeto de pesquisa "Papel dos receptores do tipo Toll e do tipo NOD-LRR na ativaçăo metaboilica e funcional de macrófagos", uma vez que se trata de utilização da mesma especie animal e de metodos experimentais similares ao referido certificado.

São Paulo, 01 de abril de 2009.

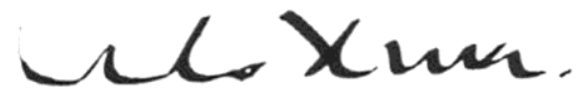

Prof. Dr. WOTHAN TAVARES DE LIMA

Coordenador -CEEA-ICB/USP 


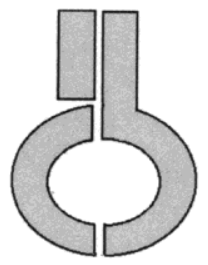

UNIVERSIDADE DE SÃO PAULO

INSTITUTO DE CIÊNCIAS BIOMÉDICAS

Cidade Universitária "Armando de Salles Oliveira"

Av. Prof. Lineu Prestes, 2415 - cep. 05508-000 São Paulo, SP - Brasil

Telefone :(55) (011) 3091.7733 - telefax : (55) (011) 30917438

e-mail: cep@icb.usp.br

Of.CEUA.43.10

NOSC/mcgn

São Paulo, 27 de julho de 2010.

\section{REF.: Protocolo $\mathrm{n}^{0}$ 109/07.}

"Papel dos receptores do tipo Toll e do tipo NOD-LRR na ativação metabóílica e funcional de macrófagos"

Prezado Professor,

Informo que a sua licença para uso de animais em experimentação, constante no protocolo em epígrafe, foi prorrogada até 06.12.2013.

Reitero que havendo alteração de metodologia e inserção de novos alunos ao projeto de pesquisa vinculado à referida licença a CEUAVICB deverá ser informada.

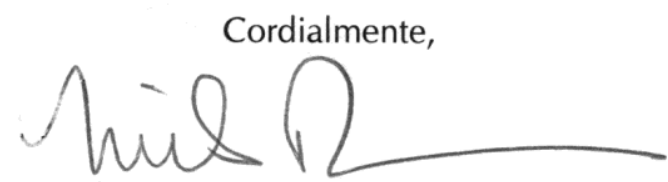

Prof. Dr. Niels Olsen Saraiva Câmara

Vice-Coordenador da Comissão de Ética no Uso de Animal - ICB /USP

Ilma.Sra.

Profa: Dra. Karina Ramalho BortoluCI

Departamento de Imunologia

Instituto de Ciências Biomédicas - USP 
Dedico este trabalho aos meus pais com muito amor
e gratidẫo. Chuito obrigada por tudo! 


\section{Agradecimentos...}

Acima de tudo, agradeço a Deus por se fazer tão presente em minha vida, me amparando nos momentos de tribulação, proporcionando saúde, discernimento e suprindo todas as minhas necessidades durante esta caminhada.

À minha querida mãe por ter aceito o desafio de ser mãe novamente e ter desempenhado esta tarefa com tanto amor e carinho! Obrigada por tudo que sempre fez e continua fazendo por mim!

Ao meu amado avô, por todo o amor, carinho, dedicação e atenção durante todas as etapas da minha vida. Por ser meu "avô-pai", por ter me ensinado o caminho do bem, por ter estado ao meu lado em todos os momentos e por ter acreditado e lutado tanto pelos meus sonhos. Obrigada por ter construído a melhor parte de mim!

Ao meu pai, que apesar da distância sempre demonstrou muito amor, amizade, carinho e preocupação em todos os momentos da minha vida. Obrigada por sempre estar ao meu lado nas etapas difíceis e compartilhar comigo as minhas alegrias.

A minha tia Sônia pelo grande apoio e incentivo em todas as etapas da minha vida.

Aos queridos tios Roberto e Cláudia que são os responsáveis pela realização deste sonho de vir para a USP. Não há palavras para agradecer tudo o que vocês têm feito por mim. Obrigada por "adotarem mais um filha". Que Deus abençôe vocês imensamente!

Ao Eduardo, por compartilhar minhas alegrias e tristezas com o mesmo apoio firme e carinhoso. Obrigada por toda a ajuda durante essa jornada, e, acima de tudo, pelo seu companheirismo, compreensão e carinho. Agradeço a Deus por ter colocado você ao meu lado na caminhada da vida. Te amo!

As minhas queridas "irmãs" Gláucia e Natália que, apesar da distância, permaneceram ao meu lado nos momentos mais difíceis, ajudando a superar as dificuldades e tropeços de mais essa etapa importante da minha vida. Obrigada $p$ essa amizade tão bonita e sincera! Vocês são anjinhos de Deus na minha vida! 
Agradeço à minha orientadora e amiga $\mathrm{Dr}^{\mathrm{a}}$ Karina Bortoluci pelo voto de confiança em mim depositado, pela amizade e pela orientação durante cada etapa deste trabalho. Muito obrigada pela dedicação, compreensão e apoio, e por ter contribuído tanto para o meu crescimento profissional e pessoal.

Ao Dro Gustavo Amarante-Mendes pela amizade, pelos conselhos, por abrir as portas da USP e me receber tão bem. Obrigada pela grande disposição em ajudar sempre e por todo apoio científico durante essa caminhada.

Às minhas queridas amigas Carininha e Alê, que me receberam com os braços e coração abertos. Obrigada por estarem ao meu lado nos momentos bons e principalmente, nos momentos difíceis, pelos conselhos e pela repreensão quando necessário. Obrigada por todo o apoio que sempre recebi e por tudo que pude aprender com vocês! Com certeza, vocês são grandes "culpadas" por eu ter chegado até aqui. Muito obrigada!

A amiga Thaís, mais nova integrante do Lab! Obrigada por todo o apoio e amizade e por em tão pouco tempo já ter se tornado uma amiga tão especial.

Obrigada aos alunos Kelly, Bruna e Danny, pela amizade e por toda a ajuda oferecida. Em especial à aluna Kelly pela contribuição na realização de algumas etapas importantes para a conclusão deste trabalho.

Muito obrigada aos amigos do laboratório da Imunologia das Parasitoses, Érika, Raquel, Henrique e Sheyla, pela grande amizade, pela mão estendida sempre, por contribuírem de forma tão importante não só para este trabalho, mas para a superação de momentos importantes desta caminhada. Raquel, muito obrigada pela sua santa paciência em me ensinar Biomol! Sua ajuda jamais será esquecida!

A todos do laboratório de Biologia Celular e Molecular que participaram tão ativamente dessa etapa da minha vida. Muito obrigada por me receberem com tanto carinho e por todo apoio que me deram, contribuindo ativamente para a realização deste trabalho.

Agradeço ao profo Maurício Rodrigues e a todos os alunos do seu laboratório que me acolheram com muito carinho na UNIFESP. 
A amiga Maria Eni pelas conversas, conselhos, pelo grande apoio e pela ajuda tão importante para a concretização deste trabalho.

As secretárias do departamento de Imunologia pela ajuda sempre que necessário.

Aos órgãos de apoio científico CNPq, FAPESP.

Aos membros da banca por aceitarem participar deste momento tão importante da minha vida.

A todos vocês, muito obrigada! 
"Ignorância, superstição e falta de bom senso é negar a existência de

Deus a priori, sem pensar de forma séria e metódica sobre o assunto. Nada é mais anticientífico do que ser ateu"

(Francis Collins - Diretor do Projeto Genoma Humano) 


\section{RESUMO}

Lage SL. Influência do reconhecimento da flagelina extra e intracelular no processo de piroptose em macrófagos. [Dissertação (Mestrado em Imunologia)]. São Paulo: Instituto de Ciências Biomédicas da Universidade de São Paulo; 2011.

A flagelina, subunidade monomérica constituinte do flagelo de bactérias móveis é uma das poucas estruturas protéicas que podem ser reconhecidas por células da imunidade inata. $\mathrm{O}$ reconhecimento acontece tanto pelo receptor transmembrânico TLR5, levando à ativação de genes inflamatórios, quanto por receptores citosólicos do tipo NOD, como NLRC4 e NAIP5, levando à ativação de caspase-1, responsável pela liberação das citocinas IL-1 $\beta$ e IL-18 e pela morte do macrófago por um processo denominado piroptose. Entretanto, os fenômenos decorrentes do reconhecimento da flagelina ainda não estão completamente elucidados. Para investigar os mecanismos moleculares envolvidos na ativação e morte do macrófago pela flagelina, macrófagos peritoneais foram estimulados com o agonista purificado das bactérias gram-positiva Bacillus subtilis e gram-negativa Salmonella typhimurium em sua forma livre, que permite seu reconhecimento extracelular pelo receptor TLR5, ou inserida no Dotap, uma vesícula lipídica catiônica que permite a sua entrega no citosol celular e ativação dos NLRs. Nós demonstramos que ambas as flagelinas citosólicas induzem produção da citocina IL-1 $\beta$ e morte celular observada por microscopia de contraste de fase, pela liberação da enzima citosólica Lactato DeHidrogenase (LDH) no sobrenadante da cultura, pela técnica de MTT e incorporação de brometo de etídio. Em contrapartida, somente as flagelinas em sua forma livre foram capazes de induzir a produção de IL-6, condizente com o reconhecimento pelo TLR5. Apesar de ambas as flagelinas possuírem as porções conservadas responsáveis pelo reconhecimento deste agonista pelos receptores TLRs e NLRs, a flagelina de $S$. typhimurium mostrou maior potencial em induzir produção de IL-1 $\beta$ e IL-6 pelos macrófagos em comparação com a flagelina de $B$. subtilis. Com relação aos eventos envolvidos no processo de piroptose em resposta à flagelina citosólica, verificamos que a produção de $\mathrm{IL}-1 \beta$ e lise celular de macrófagos se mostraram eventos subseqüentes à formação de poros na membrana celular observados pela marcação positiva para brometo de etídio em combinação com laranja de acridina. Ainda, a lise celular induzida pela flagelina citosólica ocorre de maneira independente da molécula adaptadora MyD88, o que descarta qualquer papel do TLR5 neste processo. Embora a liberação de IL-1 $\beta$ após reconhecimento intracelular de ambas as flagelinas ser um fenômeno dependente do eixo NLRC4/caspase-1, a morte celular induzida pelas flagelinas citosólicas ocorre na ausência destas moléculas, ao contrário do que prevê a literatura atual. Juntos, estes dados sugerem que a protease caspase-1 possa ser responsável por algumas características funcionais que seguem o reconhecimento da flagelina, como a produção de IL-1 $\beta$ e a formação precoce de poros na membrana, mas não pela morte da célula em si.

Palavras-chave: Macrófagos. Flagelina. Receptores do tipo Toll (TLR). Receptores do tipo NOD (NLR). Piroptose. 


\begin{abstract}
Lage SL. Influence of extra and intracellular flagellin recognition in the regulatior macrophage pyroptosis. [Masters thesis (Immunology)]. São Paulo: Instituto de Ciências Biomédicas da Universidade de São Paulo; 2011.

Flagellin, the monomeric subunit of bacterial flagellum, is one of the few protein structures that can be recognized by innate immunity cells. The recognition takes place by both, transmembranic receptor TLR5, leading to activation of inflammatory genes, and the cytosolic NOD-like receptors, NLRC4 NAIP5 leading to activation of caspase-1, which is responsible for the release of IL-1 $\beta$ and IL-18 and death of macrophages by a process called pyroptosis. However, the phenomenon arising from the recognition of flagellin has not been fully elucidated. To investigate the molecular mechanisms involved in activation and macrophage death by flagellin, peritoneal macrophages were stimulated with the purified agonist of gram-positive Bacillus subtilis and gram-negative $S$. typhimurium in their free form, which allows recognition by the extracellular receptor TLR5, or inserted into the DOTAP, a cationic lipid vesicle that enables its delivery to cell cytosol and activation of the NLRs. We demonstrated that cytosolic flagellin induces the production of IL-1 $\beta$ and cell death, observed by phase contrast microscopy, by release of the cytosolic enzyme lactate dehydrogenase (LDH) in culture supernatants, by MTT technique and incorporation of ethidium bromide. In contrast, only the flagellins in the free form were able to induce the production of IL-6, consistent with their recognition by TLR5. Although both flagellins possess the conserved portions responsible for this agonist recognition by TLRs and NLRs receptors, the flagellin of $S$. typhimurium showed greater potential to induce production of IL-1 $\beta$ and IL- 6 by macrophages, when compared to flagellin from $B$. subtilis. Regarding the events involved in pyroptosis in response to cytosolic flagellin, we found that the production of IL-1 $\beta$ and lysis of macrophages showed to be subsequent events of the formation of pores in cell membranes, observed by positive staining for ethidium bromide, in combination with acridine orange. Still, cell lysis induced by cytosolic flagellin occurs independently of the adapter molecule MyD88, which rules out any role of TLR5 in this process. Although the release of IL-1 $\beta$ after recognition of both intracellular flagellins is a phenomenon dependent on the NLRC4/caspase- 1 axis, cell death induced by cytosolic flagellin occurs in the absence of these molecules, unlike what has been provided by current literature. Together, these data suggest that the protease caspase-1 may be responsible for some functional features that follow the recognition of flagellin, as the production of IL- $1 \beta$ and the early formation of pores in the membrane, but not by cell death itself.
\end{abstract}

Keywords: Macrophage. Flagellin. Toll-like receptors. NOD-like receptors. Pyroptosis. 


\section{LISTA DE FIGURAS}

Figura 1. Representação esquemática da estrutura dos membros da família NLR.

Figura 2. Representação esquemática do complexo Inflamassoma.

Figura 3. S. typhimurium selvagem expressando flagelina leva à morte do macrófago.

Figura 4. Flagelinas purificadas de $S$. typhimurium e $B$. subtilis ativam o macrófago de maneira distinta.

Figura 5. A liberação de IL-1 $\beta$ em resposta ao estímulo com flagelina é exclusivamente dependente de NLRC4 e caspase1

Figura 6. Flagelinas purificadas de $S$. typhimurium e B. subitilis em sua forma livre induzem toxicidade de maneira distinta.

Figura 7. Flagelina citosólica de $B$. subtilis induz morte do macrófago de maneira independente de caspase-1 e do inflamassoma NLRC4.

Figura 8. A morte do macrófago induzida por flagelina de $S$. typhimurium acontece na ausência de caspase-1.

Figura 9. Morte celular induzida por flagelina citosólica é independente de MyD88.

Figura 10. citocinas IL-1 $\beta$ e IL-18 não induzem piroptose.

Figura 11. A transfecção da flagelina purificada de $B$. subtilis para 0 citosol celular induz a formação de poros na membrana plasmática.

Figura 12. A formação de poros na membrana celular após estímulo com flagelina citosólica precede a liberação de IL-1ß e a lise celular.

Figura 13. A liberação de IL-1 $\beta$ induzida por flagelina citosólica é um processo regulado pela caspase-1 e não está relacionado com a morte celular. 
Apaf-1

ASC

CARD

DAMPs

GPI

HO-1

ICE

IDO

IFN- $\gamma$

IL

iNOS

i.p.

IRFs

LAMP-1

LDH

LPS

LRR

MAL/TIRAP

MDP

MTT

MPO

MyD88

NAIP

NLRC4

NLRP

NOD

NOD-LRR/NLR

NF- $k B$

PAMP

PEC

PRR

Rip2 ou RICK
"Apoptotic protease-activating factor-1"

"Apoptosis-associated speck-like protein containing a CARD"

Domínio recrutador e ativador de caspases

"Damage-associated molecular patterns"

Glicofosfatidil inositol

Hemeoxigenase-1

"IL-1 beta converting enzyme"

Indoleamina dioxigenase

"Interferon gama"

"Interleukin"

"Inducible Nitric-oxide synthase"

"intraperitoneal"

"IFN-responsive factors"

"Lysosomal-associated membrane protein 1"

Lactato dehidrogenase

Lipopolissacarídeo bacteriano

"leucin rich repeat"

"MyD88-adaptor like/TIR-associated protein"

Muramil dipeptídeo

"3-[4,5-dimethylthiazol-2-yl]-2,5-diphenyltetrazolium bromide"

Mieloperoxidase

"Myeloid differentiation factor 88"

"Neuronal apoptosis inhibitor factors"

"ICE-protease activating factor"

"NATCH- LRR-and pyrin-domain-containing proteins"

"Nucleotide-binding oligomerization domain"

"Nucleotide-binding oligomerization domain - Leucin rich repeats"

"Nuclear factor $\kappa \mathrm{B}$ "

"Pathogen associated molecular pattern"

"Peritoneal Cavity"

"Pathern Recognition Receptors"

"Receptor-interacting caspase-like apoptosis-regulatory kinase" 
SARM

"Sterile $\alpha$ - and armadillo-motif containing protein"

SPI-1 T3SS Sistema de secreção do tipo III

TIR

"Toll/IL-1R domain"

TLR

"Toll-like Receptor"

TRAM

"Toll-receptor-associated molecule"

TRIF

"Toll-receptor-associated activator of interferon"

T4SS

Sistema de secreção do tipo IV

W.T

"Wild type" 


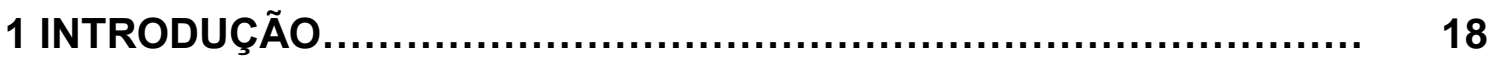

1.1 Receptores de ativação da Imunidade Inata........................... 19

1.2 Características do processo de Piroptose e seu envolvimento no controle de patógenos.

2 OBJETIVOS.................................................................................. 30

3 MATERIAL E MÉTODOS.................................................................. 32

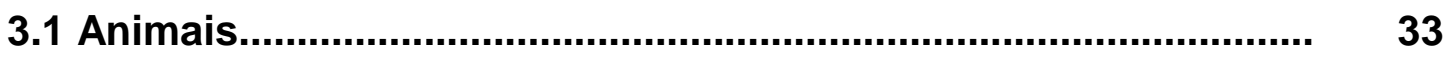

3.2 Linhagens bacterianas e flagelinas............................................ 33

3.3 Obtenção de macrófagos peritoneais........................................... 34

3.4 Transfecção da flagelina para o citosol celular............................ 34

3.5 Estimulação in vitro.................................................................. 35

3.6 Detecção das citocinas IL-1 $\beta$ e IL-6............................................ 35

3.7 Ensaio de liberação de LDH.......................................................... 36

3.8 Ensaio de Viabilidade Celular por MTT........................................ 36

3.9 Análise da formação de Poros na membrana celular................... 37

3.10 Verificação da capacidade microbicida dos macrófagos.......... 38

3.11 Análise Estatística.................................................................. 38

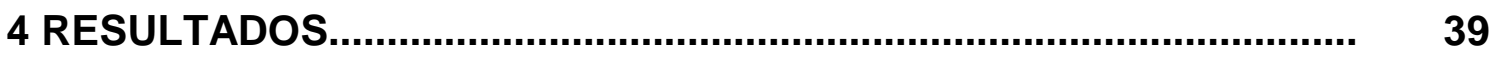

4.1 Macrófagos peritoneais são permissivos à replicação de Salmonella typhimurium deficiente em flagelina que falha em induzir piroptose

4.2 As flagelinas purificadas de Bacillus subtilis e Salmonella typhimurium modulam de maneira distinta a ativação do

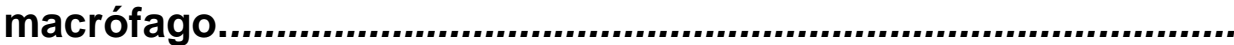

4.3 Flagelina citosólica induz morte celular de maneira independente da protease caspase-1 e do inflamassoma NLRC4.

4.4 Citotoxicidade induzida por flagelina citosólica de $B$. subtilis é independente da via de sinalização do TLR5. 
4.5 As citocinas liberadas por ação da caspase-1 não afetam a viabilidade do macrófago.

4.6 A formação de poros na membrana celular induzida por flagelina citosólica de $B$. subtilis precede a lise celular e a liberação de

IL$1 \beta$.

4.7 Macrófagos deficientes em caspase-1 sofrem cinética de eventos semelhante aos macrófagos provenientes de animal selvagem.

5 DISCUSSÃo

6 CONCLUSÃO. 
1 INTRODUÇÃO 


\subsection{Receptores de ativação da Imunidade Inata}

Os constituintes do sistema imune inato são os responsáveis pela tarefa inicial de reconhecimento e eliminação de agentes potencialmente nocivos ao organismo. Neste sentido, os macrófagos são considerados sentinelas imunológicas, pois se encontram distribuídos em diferentes tecidos, onde possuem a habilidade de reconhecer padrões moleculares que estão frequentemente associados a patógenos (Pathogen associated molecular patterns - PAMPs) e que são distintos dos padrões apresentados por células próprias (Kopp e Medzhitov, 2003). O reconhecimento destes padrões pelas células da imunidade inata é mediado por receptores codificados pela linhagem germinativa, chamados "receptores de reconhecimento de padrões" (Pathern Recognition Receptors - PRRs) que estão presentes em diferentes compartimentos celulares e são responsáveis por diversos mecanismos celulares como fagocitose e ativação celular. Dentre os receptores de ativação celular que se destacam na literatura, encontram-se os receptores do tipo Toll (Tolllike Receptors - TLR), que são encontrados na membrana plasmática ou endossomal, e receptores do tipo NOD (Nucleotide-binding oligomerization domainlike Receptors - NLR) que possuem localização citosólica.

Os TLR compreendem, até o momento, treze proteínas identificadas em mamíferos (13 receptores identificados em camundongos e 11 receptores em humanos). Os ligantes melhores caracterizados são peptidoglicanas e lipoproteínas bacterianas, âncoras de GPI (glicofosfatidil inositol) presentes em protozoários e zimozan presente em fungos (ligantes de TLR2), RNA dupla-fita, comuns em vírus (ligante de TLR3), lipopolissacarídeos (LPS) presentes na parede de bactérias gramnegativas (ligante do TLR4), flagelina presente em bactérias móveis (ligante de TLR5) e seqüências de DNA ricas em CpG não metilados, presentes em bactérias e vírus (ligante de TLR9) (Kawai e Akira, 2007).

Os TLRs são moléculas transmembranas que contêm um domínio externo à membrana com seqüências repetidas ricas em leucina, particular para cada TLR e responsável pelo reconhecimento de PAMPs, e uma cauda intracelular que mostra grande homologia com o domínio intracelular do receptor para a Interleucina (IL)-1 (IL-1R), chamada TIR (domínio Toll/IL-1R) (Gay e Keith, 1991). A ativação do TLR 
por seus ligantes induz o recrutamento de proteínas adaptadoras específicas como MyD88 (myeloid differentiation factor 88), MAL/TIRAP (MyD88-adaptor like/TIRassociated protein), TRIF (Toll-receptor-associated activator of interferon), TRAM (Toll-receptor-associated molecule) ou SARM (Sterile $\alpha$ - and armadillo-motif containing protein) (Carty et al., 2006). Cada TLR medeia respostas distintas pela associação com uma diferente combinação dessas moléculas adaptadoras que transduzem o sinal do TIR, levando à ativação de quinases e fatores de transcrição como NF-kB e IRFs (IFN-responsive factors) (Yamamoto e Akira, 2004). Dessa maneira, o reconhecimento de PAMPs por TLRs leva à transcrição de inúmeros genes que culmina na indução de uma variedade de respostas biológicas, como a produção de citocinas pró-inflamatórias, quimiocinas, Interferons do tipo I, entre outros mediadores que, juntos, serão responsáveis pela condução eficiente das respostas imunes inata e adaptativa.

Recentemente, uma nova família de PRR tem sido descrita, os receptores do tipo NOD-LRR (Nucleotide-binding oligomerization domain - Leucin rich repeats) ou NLRs, que possuem como característica peculiar sua localização citosólica e compreendem proteínas NOD, NLRP (NATCH- LRR-and pyrin-domain-containing proteins), NAIP (neuronal apoptosis inhibitor factors), Apaf-1 (apoptotic proteaseactivating factor-1) e NLRC4 (ICE-protease activating factor) (Inohara e Nunez, 2003). São proteínas formadas por 3 domínios, um domínio efetor $N$-terminal variável, um domínio central do tipo NOD e uma porção C-terminal com sequências ricas em leucina (LRR), responsável pelo reconhecimento de PAMPs (Fig.1). 


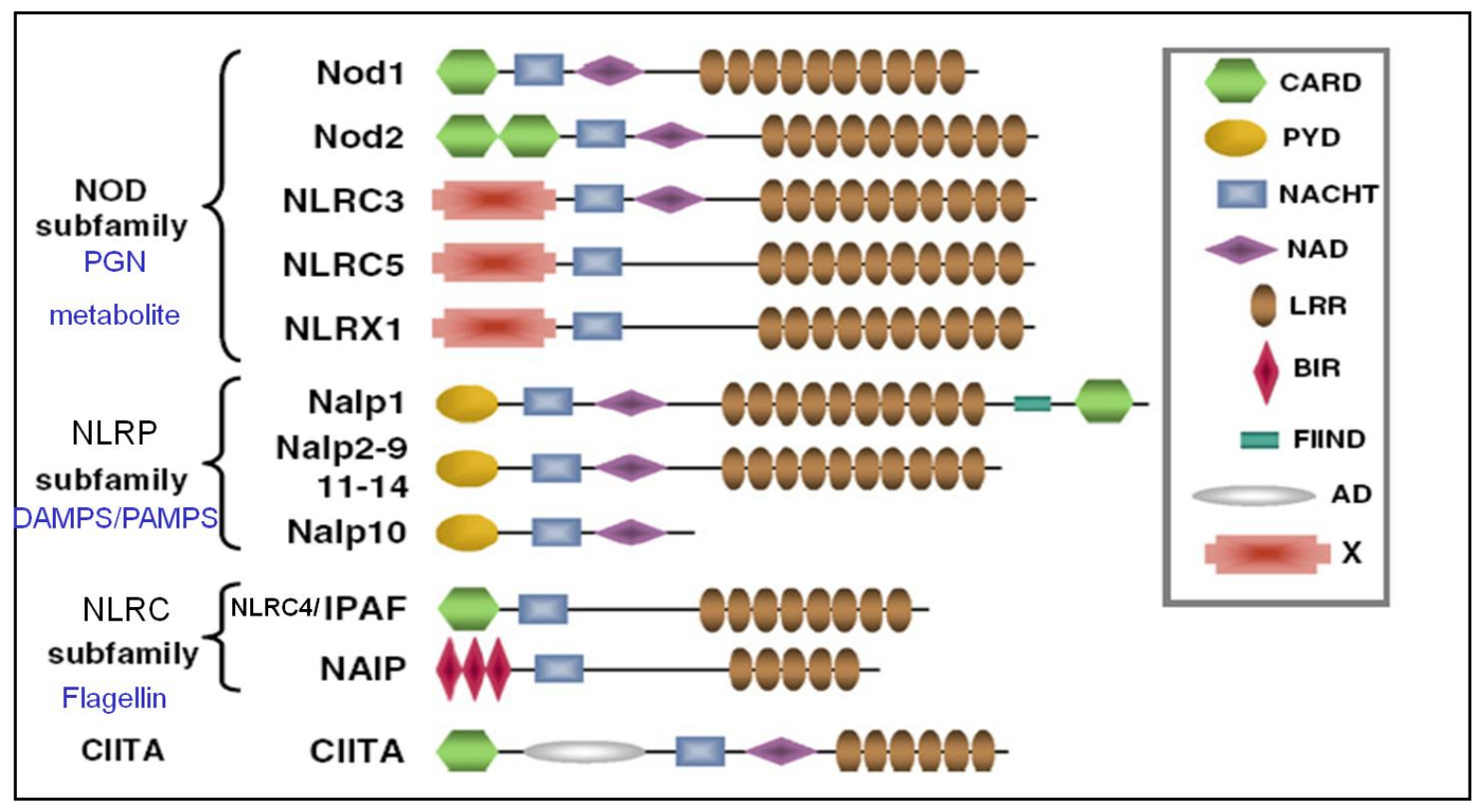

Figura 1. Representação esquemática da estrutura dos membros da família NLR. Fonte: Benko et al. (2008).

Como o conhecimento desses receptores é bem recente, pouco se sabe a respeito dos ligantes e das vias de sinalização induzidas. Dentre os membros da família dos NLR, os primeiros receptores identificados foram NOD1 e NOD2. Ambos os receptores reconhecem muropeptideos derivados do metabolismo de peptideoglicana, um dos principais componentes da parede celular de bactérias Gram-positivas e Gram-negativas (Kabelitz e Medzhitov, 2007). Enquanto NOD2 reconhece muramil dipeptideo (MDP), NOD1 detecta a presença de meso-DAP ou iE-DAP, um aminoácido característico de muitas bactérias, tais como Listeria monocytogenes e Bacillus ssp. Após ativação, NOD1 e NOD2 iniciam uma resposta pró-inflamatória dependente da ativação de NF-kB (Hayashi et al., 2001), através do recrutamento da serina-treonina kinase Rip2 ou RICK (receptor-interacting caspaselike apoptosis-regulatory kinase), a partir de interações CARD-CARD, essencial para a ativação deste fator de transcrição. Dessa maneira, após reconhecimento de PAMPs no citosol, estes receptores iniciam uma cascata de sinalização intracelular que culmina na transcrição de inúmeros genes pró-inflamatórios de maneira semelhante à resposta dos TLRs.

Outros membros da família dos receptores NLR são denominados inflamassomas. Dentre esses receptores, podemos citar os inflamassomas NLRP1, 
o NLRP3 e o NLRC4. Sabe-se que o NLRP1 reconhece a toxina letal anthrax, enquanto que o NLRP3 parece reconhecer múltiplos agonistas de origem microbiana e do hospedeiro, incluindo RNA bacteriano, RNA dupla fita presente em vírus, ácido úrico e efluxo celular de potássio (Bortoluci e Medzhitov, 2010). O fato dos receptores NLRP3 serem ativados em resposta ao ácido úrico e efluxo de potássio sugere que esses NLR detectam sinais de perigo, em adição a estímulos derivados de patógenos (Franchi et al., 2006). Por fim, o inflamassoma NLRC4 foi identificado por responder à flagelina intracelular, proveniente de bactérias como $S$. typhimurium e L. pneumophila (Iwasaki e Medzhitov, 2004; Amer et al., 2006; Franchi et al., 2006). Além do NLRC4, o receptor NAIP5 (Neuronal apoptosis inhibitory protein5), outro membro da família dos NLR que reconhece a flagelina intracelular, foi identificado a partir de estudos que mostraram que camundongos $A / J$, mutantes para este receptor, são suscetíveis à infecção por L. pneumophila (Zamboni et al., 2006).

Uma vez ativados pela interação com PAMPs ou sinais de perigo, NLRP1, NLRP3 e NLRC4, orquestram a montagem de um complexo macromolecular que atua como plataforma intracelular para o processamento e ativação da protease caspase-1. Esta estrutura formada por um membro NLR e pela molécula adaptadora ASC (apoptosis-associated speck-like protein containing a CARD) foi denominada de inflamassoma como um análogo do apoptossoma que direciona a ativação da caspase-9 durante o processo de apoptose (Fig. 2) (Martinon et al., 2002; Martinon et al., 2007). Assim, enquanto a ativação de NOD1 e NOD2 por seus ligantes induz a ativação de NF-kB, as proteínas NLRPs e NLRC4 iniciam o processo inflamatório pela ativação da caspase-1.

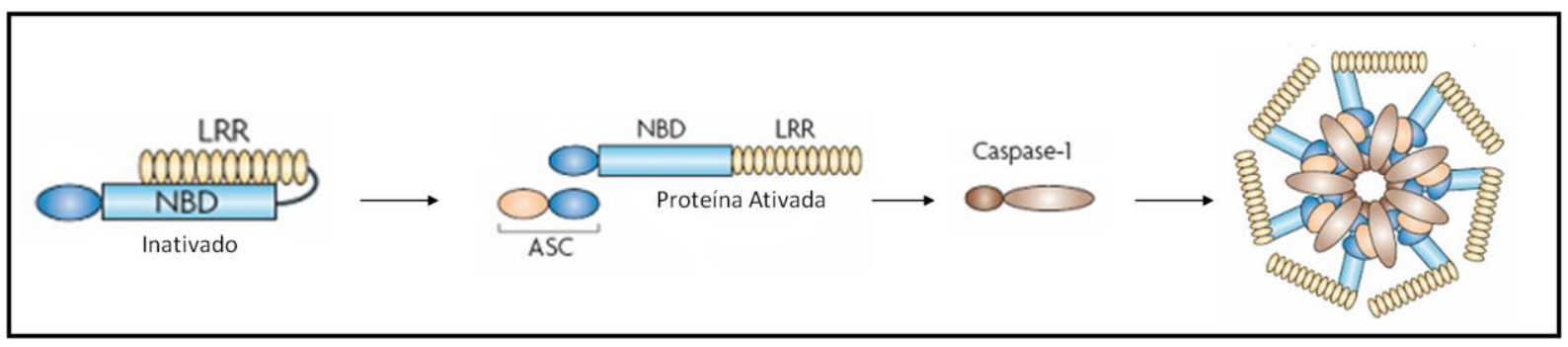

Figura 2. Representação esquemática do complexo inflamassoma.

Fonte: Ting et al. (2008). 
Dessa maneira, após ativação por seus agonistas, NLRP1, NLRP3 e NLRC4 sofrem auto-oligomerização através do seu dominio de ligação a nucleotídios (Faustin et al., 2007). Alguns NLRs, incluindo o NLRP3, possuem o domínio pyrin (PYD) que recruta a proteína adaptadora ASC, através de interações PYRIN-PYRIN. ASC, por sua vez, contém um domínio C-terminal recrutador e ativador de caspase (CARD) que se liga e recruta a pró-caspase-1, via interações CARD-CARD (Martinon et al., 2007). Outros NLRs, como o NLRC4, contém o dominio CARD e podem interagir diretamente com a caspase-1 (Poyet et al., 2001). Entretanto, o fato de que a ativação de caspase-1 mediada por $S$. typhimurium se encontra reduzida em macrófagos deficientes de ASC, sugere que essa molécula facilita a ativação de caspase-1 mesmo não sendo absolutamente requerida para a sua interação com o NLRC4 (Mariathasan et al., 2004).

A cisteíno-protease caspase-1 é expressa no citosol como um zimógeno inativo e a associação da pró-caspase-1 com o complexo inflamassoma permite 0 seu processamento e ativação (Nicholson, 1999; Martinon e Tschopp, 2007). Assim, após recrutamento para o interior da estrutura do inflamassoma, a pró-caspase-1 sofre auto-ativação por clivagem proteolítica tornando-se um heterodímero enzimaticamente ativo. Uma vez ativa, a caspase-1 medeia o processamento e ativação das citocinas pró-inflamatórias IL-1 $1 \beta$ e IL-18 que são geradas no citosol na forma de precursores inativos (Fantuzzi e Dinarello, 1999). Após clivagem pela caspase-1, essas citocinas se tornam biologicamente ativas e são liberadas para 0 meio extracelular. Além disso, a ativação de caspase-1 como resultado do engajamento de inflamassomas tem sido relacionada à indução de um processo de morte celular intrinsecamente pró-inflamatório, denominado de piroptose (Brennan e Cookson, 2000; Fink e Cookson, 2006). Esta via pró-inflamatória de morte celular é exclusivamente dependente de caspase-1 e leva à rápida lise celular com liberação do conteúdo intracelular pró-inflamatório, que, juntamente com a liberação das citocinas IL-1 $\beta$ e IL-18 são responsáveis pela grande resposta inflamatória que acompanha este processo (Ting et al., 2008).

Assim, a ativação de receptores dos macrófagos por PAMPs induz a produção de uma série de moléculas efetoras envolvidas na capacidade microbicida dessas células, na condução e resolução da resposta inflamatória e no 
desenvolvimento da resposta imune adaptativa (Iwasaki e Medzhitov, 2004). Essas moléculas podem ser produtos de genes pró-inflamatórios (como citocinas inflamatórias e quimiocinas), ou provenientes do metabolismo lipídico (leucotrienos e prostaglandinas) e bioquímico dessas células (enzimas como NO-sintase induzida (iNOS), NADPH-oxidase, mieloperoxidase (MPO), hemeoxigenase-1 (HO-1) e indoleamina dioxigenase (IDO)). Todas essas vias compõem 0 arsenal de mecanismos que os fagócitos dispõem para controlar os microorganismos ingeridos. A geração de intermediários reativos do oxigênio e do nitrogênio como resultado da ativação por TLRs há muito tem sido considerada de fundamental importância para a degradação dos microorganismos ingeridos, uma vez que a deficiência nas enzimas participantes desse processo resulta na susceptibilidade a diversos patógenos (Holscher et al., 1998; Schappi et al., 2008; Stasia et al., 2009). Porém, a susceptibilidade a infecções apresentada por animais deficientes em alguns membros da família NLR elou caspase-1, confere um papel igualmente importante para essa protease e para os inflamassomas no controle de patógenos (Suzuki et al., 2007).

\subsection{Características do processo de Piroptose e seu envolvimento no controle de patógenos}

Sabe-se que uma grande variedade de microorganismos patogênicos leva as células eucarióticas à morte, seja por consequência da infecção, seja pela ação direta de produtos tóxicos (Fink e Cookson, 2005). Ou seja, os patógenos, além de seu papel na ativação direta dos fagócitos com conseqüências para a resposta imune, também influenciam a resposta imune indiretamente, modulando o destino das células hospedeiras. Embora a apoptose seja a via de morte celular programada mais bem estudada, recentemente tem sido descrita outra via de morte celular caracterizada por ser exclusivamente dependente da atividade da caspase-1 a partir da ativação de receptores citosólicos do tipo NOD em resposta a estímulos derivados de patógenos.

As caspases são membros de uma família de cisteíno-proteases que clivam um número limitado de substratos presentes após resíduos de ácido aspártico. Embora a maioria dos estudos tenham focado nas caspases apoptóticas, a caspase- 
1 é melhor conhecida por seu papel na inflamação e nas respostas imunes à estímulos patogênicos (Nicholson, 1999; Martinon e Tschopp, 2007). A caspase-1 foi primeiro reconhecida como a protease responsável por processar os precursores inativos das citocinas IL-1 $\beta$ e IL-18 em citocinas pró-inflamatórias maduras e foi inicialmente chamada de enzima conversora de IL-1 $\beta$ (IL-1- Converting Enzyme ICE) (Fantuzzi e Dinarello, 1999). Entretanto, a ativação de caspase-1, após engajamento dos inflamassomas, não resulta apenas em liberação de tais citocinas, mas também em rápida morte celular caracterizada por perda da integridade e posterior ruptura da membrana plasmática com liberação do conteúdo intracelular inflamatório (Brennan e Cookson, 2000; Fink e Cookson, 2006).

O termo Piroptose (do grego "pyro", significando fogo ou febre, e "ptosis" relacionado a uma falha), foi usado para descrever esse processo de morte celular altamente regulada e inerentemente pró-inflamatória. Assim, apesar de a piroptose se apresentar como uma forma de morte celular programada e molecularmente regulada como a apoptose, os mecanismos moleculares envolvidos em seu controle e, especialmente, suas consequências para a resposta imune, são distintas daquelas observadas para a apoptose, a qual inibe ativamente a inflamação.

Enquanto a apoptose é mecanisticamente definida pelo requerimento de um subgrupo da família das caspases executoras, chamadas de caspases apoptóticas, como caspase-3, 6 e 9, a caspase-1 é a responsável pelas mudanças morfológicas observadas na piroptose. De acordo com isso, sabe-se que a caspase-1 não está envolvida no processo de apoptose e camundongos deficientes em caspase-1 sofrem apoptose e se desenvolvem normalmente (Kuida et al., 1995; Li et al., 1995). Da mesma maneira, as caspases apoptóticas não estão envolvidas na piroptose e os seus substratos não sofrem proteólise durante a piroptose (Chen et al., 1996b) (Brennan e Cookson, 2000; Fink e Cookson, 2006; Bergsbaken e Cookson, 2007). A clivagem do DNA cromossomal, por exemplo, é um evento que frequentemente está associado à apoptose, onde ocorre a proteólise mediada por caspases do ICAD que libera a DNase CAD para o núcleo celular (Fink e Cookson, 2005). No núcleo, CAD cliva DNA entre nucleossomos, resultando nos fragmentos de DNA oligonucleossomais de aproximadamente $180 \mathrm{pb}$, característicos da apoptose. Entretanto, o dano ao DNA também ocorre durante o processo de piroptose, porém, 
na piroptose, não ocorre ativação de CAD. A clivagem de DNA durante a piroptose resulta da atividade de outra nuclease, ativada por caspase-1 e até hoje não identificada, que não produz o padrão de fragmentação oligonucleossomal que é característica da apoptose (Fink e Cookson, 2006; Bergsbaken e Cookson, 2007).

Sabe-se que a lise celular durante a piroptose resulta de um processo altamente regulado pela atividade da caspase-1. Fink e Cookson (2006) demonstraram que a lise celular que ocorre durante a piroptose em macrófagos infectados por $S$. typhimurium, é um processo mediado pelas células hospedeiras que requer ativação de caspase-1 para gerar a formação de poros na membrana plasmática com um diâmetro funcional de 1.1 a $24 \mathrm{~nm}$. Mais recentemente, Silveira e Zamboni (2010) demonstraram que a formação de poros na membrana de células infectadas por L. pneumophila é um processo altamente regulado, dependente da atividade da caspase-1 a partir da ativação do inflamassoma NLRC4. Tem sido então proposto, que esses poros dissipam gradientes iônicos celulares, mas permitem a retenção de constituintes citoplasmáticos maiores, levando à pressão osmótica líquida aumentada. Isso causa influxo de água, inchaço celular e posterior lise osmótica com liberação de conteúdo intracelular inflamatório (Fink e Cookson, 2006; Silveira e Zamboni, 2010).

As citocinas IL-1 $\beta$ e IL-18 sofrem ativação dependente de caspase-1 e sua liberação acompanha o processo de piroptose. Ambas desempenham um papel essencial na patogênese de uma variedade de doenças inflamatórias e autoimunes. A IL-1 é um potente pirógeno endógeno, estimulador da febre, da migração de leucócitos para os tecidos e da expressão de citocinas e quimiocinas (Delaleu e Bickel, 2004). A IL-18 induz a produção de IFN- $\gamma$ que é importante para ativação de células T, macrófagos e outros tipos celulares (Nakanishi et al., 2001).

Embora amplamente estudadas, o mecanismo de liberação dessas citocinas não está completamente elucidado. Há algumas evidências de que o processo de formação de poros na membrana plasmática seja requerido para a liberação dessas citocinas. Foi recentemente demonstrado que a liberação de IL-1 $\beta$ para o meio extracelular está temporalmente relacionada com a formação de poros dependentes de caspase-1 na membrana de macrófagos durante infecção por L. pneumophila (Silveira e Zamboni, 2010). Além disso, foi demonstrado que a lise não é requerida 
para a liberação dessas citocinas uma vez que inibidores farmacológicos da lise celular não foram capazes de impedir a formação de poros nem a liberação dessas citocinas (Fink e Cookson, 2006). Assim, a produção dessas citocinas de maneira concomitante ao processo de morte celular contribui para a resposta inflamatória elicitada pelas células que sofrem piroptose.

A indução de piroptose por bactérias patogênicas mostrou ser um processo dependente de um sistema de secreção ativo presente nessas bactérias que transloca proteínas bacterianas para o citosol celular, como o sistema de secreção do tipo III (SPI-1 T3SS) de S. typhimurium e do tipo IV (T4SS) de L. pneumophila, uma vez que macrófagos infectados por bactérias mutantes para componentes da maquinaria de secreção têm ativação de caspase-1 e produção de IL-1 $\beta$ abolidas ou altamente inibidas e falham em sofrer piroptose (Chen et al., 1996a; Lundberg et al., 1999; Brennan e Cookson, 2000; Franchi et al., 2006; Miao et al., 2006). Assim, diversos estudos demonstraram que a ativação de caspase-1 dependente do inflamassoma NLRC4, requer a presença de flagelina bacteriana no citosol, sugerindo que o NLRC4 responde à flagelina translocada para o citosol, via sistemas de secreção. De acordo com isso, a formação de poros dependente de caspase-1 na membrana de células infectadas por $L$. pneumophila demonstrou ser um processo desencadeado em resposta a bactérias expressando flagelina e sistema de secreção funcional. Além disso, a transfecção da flagelina purificada de $L$. pneumophila com vesículas lipídicas catiônicas DOTAP no citosol celular foi suficiente para desencadear a formação de poros dependente de caspase- 1 e piroptose (Silveira e Zamboni, 2010).

Além do NLRC4, o receptor NAIP5, parece ser fundamental no controle da $L$. pneumophila por macrófagos, por um mecanismo dependente da ativação de caspase-1 e da presença da flagelina bacteriana no citosol (Molofsky et al., 2006; Zamboni et al., 2006; Lightfield et al., 2008). De maneira interessante, a ativação de caspase-1 dependente de NLRC4 tem sido observada durante infecção por patógenos que não expressam flagelina, como Pseudomonas e Shiguella, o que sugere que este receptor responda a algum outro componente bacteriano transportado para o citosol ainda não identificado (Franchi et al., 2007; Suzuki et al., 2007). 
Dessa maneira, tem sido sugerido um papel para caspase-1 como um importante mecanismo de controle de patógenos intracelulares. Comparados com animais selvagens (WT), animais deficientes em caspase-1 são mais susceptíveis a um grande número de infecções (Lara-Tejero et al., 2006; Raupach et al., 2006). Camundongos deficientes em caspase-1 sucumbem à infecção oral por $S$. typhimurium mais rapidamente que animais WT e têm carga bacteriana aumentada nas placas de peyer do linfonodo mesentérico e baço. Estes animais também possuem carga bacteriana aumentada no baço e no fígado após infecção intraperitoneal por $S$. typhimurium, sugerindo que a caspase-1 possui papel protetor independente da rota de infecção (Raupach et al., 2006).

As citocinas IL-1 $\beta$ e IL-18, ambas substratos da caspase-1, participam do controle da infecção por S. typhimurium, uma vez que camundongos deficientes em qualquer uma dessas citocinas têm números aumentados de bactéria nos órgãos infectados e morrem mais rapidamente que animais WT (Raupach et al., 2006). Foi demonstrado que mesmo após períodos extensos de infecção, o camundongo knockout para caspase-1 é incapaz de controlar a infecção por Shigella (Sansonetti et al., 2000). Com o uso de animais knockout para IL-1 $\beta$ e IL-18 demonstrou-se que a IL-1 $\beta$ é a responsável pela intensidade da inflamação aguda observada pela infecção por Shigella, enquanto a IL-18 é a responsável por elicitar uma resposta antibacteriana efetiva. Durante a infecção, entretanto, essas citocinas são ativadas e liberadas concomitantemente com o processo de piroptose. Então, o processo que medeia a produção dessas citocinas está intrinsecamente ligado ao dano celular, sugerindo que o papel da caspase-1 durante a defesa do hospedeiro contra patógenos intracelulares não é devido somente à produção dessas citocinas.

Assim, além de regular a produção dessas citocinas que possuem importante papel na inflamação, o processo de piroptose desencadeado por essa protease, poderia, por si só, atuar como mecanismo de controle de patógenos. A própria lise celular expõe a bactéria a outros mecanismos antimicrobianos por destruir o nicho intracelular necessário para a replicação e disseminação da bactéria, bem como, promove uma intensa resposta inflamatória pela liberação do conteúdo intracelular que pode contribuir para conter a infecção. Já foi demonstrado que camundongos deficientes em caspase-1 são mais susceptíveis à infecção por Francisella turalensis 
(Henry e Monack, 2007) do que camundongos que perderam a expressão de ambas as citocinas, corroborando com a idéia de que algum outro mecanismo dependente de caspase-1 deve contribuir para o controle da infecção. No caso da infecção por $L$. pneumophila foi demonstrado que ambos, morte celular e controle da replicação bacteriana são processos relacionados e mediados pelo eixo NAIP5-caspase-1 em resposta à presença da flagelina bacteriana no citosol celular (Zamboni et al., 2006). Além disso, a IL-1 parece não ter papel importante durante a infecção por $L$. pneumophila, o que sugere que, pelo menos em parte, o processo de morte celular deve contribuir para 0 controle da infecção, em adição à outras funções dependentes de caspase-1 que ainda não foram descritas.

Diante dessas observações, podemos verificar a importância da ativação de genes inflamatórios e regulação dos processos de morte celular por receptores TLR e NLR para o controle de infecções. O fato de estes receptores compartilharem os mesmos ligantes pode sugerir uma cooperação entre esses no sentido de otimizar a ativação celular frente a determinadas infecções (Kabelitz e Medzhitov, 2007). Nesse sentido, a flagelina, subunidade monomérica que polimeriza para formar 0 flagelo, estrutura presente em bactérias móveis, e muitas vezes relacionada à patogenicidade microbiana, se torna um excelente modelo experimental para 0 estudo desses receptores. A flagelina é uma das poucas estruturas protéicas capazes de serem reconhecidas pelo sistema imune inato. $O$ reconhecimento extracelular da flagelina se dá pelo TLR5 (Hayashi et al., 2001). Porém, a flagelina pode ser levada ao citosol através de sistemas de transporte, presentes em bactérias virulentas, como o sistema de secreção tipo III (SPI-1 T3SS) de $S$. typhimurium e do tipo IV (T4SS) de L. pneumophila, onde é capaz de ativar os receptores NLRC4 e NAIP5 (Amer et al., 2006; Franchi et al., 2006; Zamboni et al., 2006). Assim, os receptores do tipo Toll e do tipo NOD parecem compartilhar os mesmos ligantes, porém as circunstâncias nas quais os diferentes receptores interagem e a relevância deste fato para o controle das infecções ainda necessita de muitas investigações. Na tentativa de elucidar esses aspectos, a proposta central deste projeto foi investigar a influência do reconhecimento extra e intracelular da flagelina na ativação de macrófagos e regulação do processo de piroptose. 
2 OBJETIVOS 


\section{Objetivo Central}

Verificar a influência do reconhecimento extra e intracelular da flagelina na ativação de macrófagos e modulação do processo de piroptose.

\section{Objetivos específicos:}

- Avaliar a indução do processo de piroptose por Salmonella typhimurium LT21412 (selvagem) e Salmonella typhimurium LT22157 (sem flagelina);

- Verificar a influência do reconhecimento extra e intracelular da flagelina na ativação do macrófago e indução de morte celular, utilizando para isso as flagelinas purificadas das bactérias $S$. typhimurium e $B$. subtilis administradas em sua forma livre ou inseridas em vesículas lipídicas catiônicas que permitem sua entrega no citosol celular;

- Estudar a cinética de eventos envolvidos no processo de piroptose após estímulo com flagelina: formação de poros na membrana celular, liberação da citocina IL-1 $\beta$ e indução da morte celular;

- Averiguar o papel da molécula adaptadora MyD88, do inflamassoma NLRC4 e da protease Caspase-1 no processo de piroptose induzido pela flagelina em macrófagos, utilizando macrófagos provenientes de animais C57BL/6 (selvagens) e deficientes em MyD88, NLRC4 e caspase-1. 
3 MATERIAL E MÉTODOS 


\subsection{Animais}

Camundongos C57BL/6 e knockouts para MyD88, com 6-8 semanas de idade, mantidos em condições SPF (Specific-pathogen free), foram fornecidos pelo Biotério de camundongos isogênicos do Departamento de Imunologia, ICB-USP. Camundongos C57BL/6 e knockouts para Caspase-1 e NLRC4, com 6-8 semanas de idade, mantidos em condições SPF (Specific-pathogen free), foram fornecidos pelo Biotério de camundongos isogênicos da Universidade Federal de São Paulo UNIFESP.

\subsection{Linhagens bacterianas e flagelinas}

As linhagens bacterianas Salmonella enterica serovar typhimurium LT21412 (selvagem) e S. typhimurium LT22157 (sem flagelina) (gentilmente cedidas pelo Prof. Luis Carlos Ferreira, Departamnento de Microbiologia, ICB-USP) foram estocadas em meio Luria Bertani (LB) a $-80^{\circ} \mathrm{C}$. Para serem utilizadas, as bactérias primeiramente foram semeadas em meio LB ágar por 1 dia para crescimento das colônias. Depois, uma das colônias foi recolhida e cultivada em meio LB líquido por $12 \mathrm{~h}$ sob agitação $(200 \mathrm{rpm})$ a $37^{\circ} \mathrm{C}$. Posteriormente, este caldo LB foi diluído 10 vezes, e, então, cultivado sob agitação por mais $4 \mathrm{~h}$ para obtenção das bactérias na fase exponencial, de acordo com a curva de crescimento padrão.

Ambas as flagelinas utilizadas, a flagelina purificada da bactéria $S$. typhimurium (FliCi) e a flagelina purificada da bactéria Bacillus subtilis (FLA-BS), foram obtidas da empresa InivoGen, reconstituídas com água livre de endotoxina e estocadas a $-20 \stackrel{\circ}{\mathrm{C}}$. 


\subsection{Obtenção de macrófagos peritoneais}

Camundongos C57BL/6 ou knockouts para MyD88, Caspase-1 e NLRC4 foram inoculados intraperitonealmente (i.p) com amido de batata "starch" 1\% (Sigma) para enriquecimento do peritônio por macrófagos. Após 4 dias, os camundongos foram sacrificados em câmara fechada por inalação de Halotano (Cristália). Foram injetados $5 \mathrm{ml}$ de PBS (1X) estéril e gelado na cavidade peritoneal para obtenção da suspensão celular. Este procedimento foi realizado pelo menos duas vezes. A suspensão de células foi centrifugada a $1000 \mathrm{rpm}$ por $5 \mathrm{~min}$, e ressuspensa com 5 $\mathrm{ml}$ de meio RPMl 1640 completo, suplementado com 3\% de SBF (Sigma). Seguiu-se então, a contagem das células em câmara de Neubauer, após diluição da suspensão celular a 1:20 em azul de tripan. Após a contagem, onde verificamos a obtenção de, aproximadamente, $6 \times 10^{6}$ células por peritônio, as células foram então plaqueadas, em placas de 96 poços (Costar), na concentração de $3 \times 10^{5}$ células por poço, em meio RPMI 1640 completo, suplementado com 3\% de SBF (Sigma), por pelo menos $4 \mathrm{~h}$, a $37^{\circ} \mathrm{C}$, em atmosfera contendo $5 \%$ de $\mathrm{CO}_{2}$, para que a população de macrófagos seja enriquecida por aderência. Após esse período, as células não aderentes foram retiradas através de vigorosas lavagens utilizando meio RPMI morno.

\subsection{Transfecção da flagelina para o citosol celular}

As flagelinas purificadas das bactérias $B$. subtilis e $S$. typhimurium foram inseridas em vesículas lipídicas catiônicas, chamadas DOTAP (dioleoyl trimethylammonium propane), de acordo com as instruções do fabricante. Brevemente, a flagelina purificada é adicionada ao DOTAP, na concentração de $1 \mu \mathrm{g}$ de flagelina para cada $5 \mu$ de DOTAP, na presença de HBS (HEPES-salina tamponada). Essa mistura é homogeneizada gentilmente por 1 minuto e, então, mantida por 15 minutos em temperatura ambiente para a formação de complexos estáveis gerados espontaneamente. Após esse período, adiciona-se a quantidade apropriada de meio de cultura ao preparado flagelina/DOTAP (FLiCiDot ou FLAB.SDot) e este é, então, diretamente adicionado às culturas. Desta maneira, a flagelina pode ser levada ao citosol celular, como têm sido descrito na literatura 
(Buzzo et al., 2010). Uma vez que a flagelina de $S$. typhimurium possui aproximadamente o dobro do tamanho da flagelina de $B$. subtilis, as concentrações em $\mu \mathrm{g} / \mathrm{ml}$ foram ajustadas para que ambas ficassem na mesma concentração molar. Sendo assim, 1, 3 e $6 \mu \mathrm{g}$ da flagelina de $B$. subtilis correspondem a 1,8; 5,4 e 10,8 $\mu \mathrm{g}$ da flagelina de S.typhimurium. Isto representa a concentração molar de 1,4 e $8 \mathrm{x}$ $10^{-10} \mathrm{M}$ para ambas as flagelinas.

\subsection{Estimulação in vitro}

Os macrófagos peritoneais obtidos como descrito anteriormente, foram cultivados em placas de 96 poços (Costar) $\left(10^{5}\right.$ células/poço), em meio RPMI completo, suplementado com $3 \%$ de SBF (Sigma), a $37{ }^{\circ} \mathrm{C}$ e a $5 \%$ de $\mathrm{CO}_{2}$ e foram estimulados in vitro com flagelina purificada proveniente de $B$. subtilis ou $S$. typhimurium em sua forma livre, FLA-B.S. e FliCi, respectivamente, ou inseridas em vesículas lipídicas catiônicas (DOTAP), FLA-B.S.Dot ou FliCiDOT, nas concentrações de 1, 4 e $8 \times 10^{-10} \mathrm{M}$. Como controle, as células foram colocadas em meio de cultura sozinho ou juntamente com a vesícula DOTAP vazia (Dot). As células também foram estimuladas com 1,5 , ou $10 \mathrm{mg} / \mathrm{ml}$ das citocinas recombinantes IL-1 $\beta$, IL-18 (Serotec) ou ambas, para verificação do seu papel na morte celular. Após períodos de 6 e 24 h de estímulo, os sobrenadantes da cultura foram analisados quanto à liberação de LDH e/ou citocinas produzidas, e a cultura celular foi submetida ao ensaio de MTT para a análise da viabilidade celular.

\subsection{Detecção das citocinas IL-1 e IL-6}

A análise da produção das citocinas pró-inflamatórias IL-1 e IL-6 nos sobrenadantes das culturas foi determinada por ELISA sandwich de captura utilizando o kit comercial proveniente da Pharmingen, de acordo com as instruções do fabricante. 


\subsection{Ensaio de liberação de LDH}

O ensaio que quantifica a liberação da enzima citosólica Lactato DeHidrogenase (LDH), indicativo de perda da integridade da membrana celular, é comumente utilizado para estimar o número de células não viáveis presentes em uma amostra. Utilizamos o Kit comercial da marca DOLES que realiza leitura colorimétrica no sobrenadante da cultura celular. Este ensaio é baseado na conversão de lactato em piruvato na presença de LDH com redução paralela de NAD em NADH. Brevemente, $50 \mu$ do sobrenadante da amostra foram coletados e acrescidos de $100 \mu \mathrm{l}$ de solução de alúmen férrico e substrato, na proporção de $1 \mu \mathrm{l}$ de alúmen férrico para $17 \mu \mathrm{l}$ de substrato, mantendo-se a $37^{\circ} \mathrm{C}$ por $3 \mathrm{~min}$. Após esse período, acrescenta-se $100 \mu \mathrm{l}$ da solução de NAD e fenasina metasulfato, na concentração de $1 \mu \mathrm{l}$ dessa solução para $20 \mu \mathrm{l}$ de água destilada, mantendo-se a 37 ${ }^{\circ} \mathrm{C}$ por mais $5 \mathrm{~min}$. A leitura foi realizada em espectrofotômetro de placa a $510 \mathrm{~nm}$. Para a obtenção de um controle positivo, indicativo de lise máxima, foi utilizado controle com Triton 1\%, e para um controle negativo, indicativo de lise mínima, o sobrenadante da cultura de macrófagos não estimulados ou tratados com Dot. Dessa maneira, o cálculo da porcentagem de lise celular, diretamente proporcional à quantidade de LDH liberado no meio de cultura, foi realizado através da seguinte fórmula: $100 \times$ (amostra - controle da amostra)/(controle positivo - controle negativo).

\subsection{Ensaio de Viabilidade celular por MTT}

A citotoxicidade celular foi avaliada através da observação direta das células em microscópio de luz, como uma medida qualitativa, e através do ensaio de MTT. O MTT (3-[4,5-dimethylthiazol-2-yl]-2,5-diphenyltetrazolium bromide) é um sal tetrazólico, solúvel em água, que é convertido em formazan insolúvel, de coloração roxa, por clivagem do anel tetrazólico pela enzima succinato deidrogenase, no interior da mitocôndria. $O$ produto formazan é impermeável à membranas celulares e, dessa maneira, se acumula no interior de células vivas (Fotakis e Timbrell, 2006). Primeiramente, foi preparada a solução de MTT na concentração de $5 \mathrm{mg} / \mathrm{ml}$ em PBS (1X). Esta solução foi filtrada em filtro de 0,22 $\mu \mathrm{m}$. Após o período de estímulo, 
adiciona-se na cultura celular um volume da solução de MTT a $5 \mathrm{mg} / \mathrm{ml}$ equivalente a $10 \%$ do volume total de cada poço e incuba-se a placa durante $2 \mathrm{~h}$ a $37^{\circ} \mathrm{C}, 5 \%$ de $\mathrm{CO}_{2}$; Após o período de incubação, retira-se todo o sobrenadante, cuidadosamente para não ferir a monocamada de células e adiciona-se $100 \mu$ da solução de Isopropanol/ $/ \mathrm{HCl}$ que consiste em $120 \mu \mathrm{l}$ de $\mathrm{HCl}$ fumegante dissolvidos em $80 \mathrm{ml}$ de Isopropanol. Após homogeneização cuidadosa, esta solução de Isopropanol/HCl irá dissolver os cristais de formazan que foram formados. Lê-se absorbância a 570 nm; Dessa forma, estimamos o número de células viáveis na cultura celular, através da porcentagem sobre o controle positivo de viabilidade (macrófagos não estimulados ou tratados com Dot).

\subsection{Análise da formação de Poros na membrana celular}

Macrófagos peritoneais provenientes de animais C57BL/6 foram obtidos como descrito anteriormente, após 4 dias de injeção de Starch, e foram cultivados em placa de cultura de 96 poços (Costar) e os macrófagos foram estimulados com flagelina purificada proveniente de $B$. subtilis inseridas em vesículas lipídicas catiônicas (FLA-B.S.Dot), na concentração de $6 \mu \mathrm{g} / \mathrm{ml}$ ou $8 \times 10^{-10} \mathrm{M}$. Como controle negativo, as células foram colocadas em meio de cultura e/ou com Dot. Após períodos de 1,3, 4, 5 e 6 h de estímulo, adicionou-se uma solução de PBS contendo $25 \mu \mathrm{g} / \mathrm{ml}$ de Brometo de Etídio e $25 \mu \mathrm{g} / \mathrm{ml}$ de laranja de acridina. Todas as células foram coradas com Laranja de acridina enquanto apenas as células com poros na membrana permitiram a difusão de Brometo de Etídio para o interior do citosol. As imagens foram obtidas utilizando microscópio invertido de fluorescência nas objetivas de 20 e 40X e a porcentagem de poros ou de células coradas com brometo de etídio foi obtida com o auxílio do software ImageJ. 


\subsection{Análise da capacidade microbicida dos macrófagos}

O método utilizado para verificar a capacidade microbicida de macrófagos frente à infecção por $S$. typhimurium (selvagem e mutante sem flagelina), in vitro, foi descrito por Franchi e col. (Franchi et al., 2006). Em resumo, macrófagos peritoneais

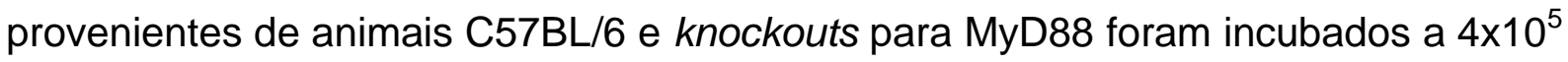
células por poço, em placa de 96 poços e infectadas ou não com S. typhimurium selvagem ou mutante ( $\mathrm{MOI} 10: 1$, bactéria:macrófago), por 30 min a $37^{\circ} \mathrm{C}$. As placas contendo os macrófagos infectados foram centrifugados a $1000 \mathrm{rpm}$ por $10 \mathrm{~min}$ para permitir a mesma taxa de ingestão pelos macrófagos das bactérias selvagem e mutante, pois esta última não apresenta motilidade pela ausência de flagelo. Após a infecção, as culturas foram lavadas e incubadas com meio RPMI suplementado com $3 \%$ de soro fetal bovino na presença de $100 \mu \mathrm{g} / \mathrm{ml}$ de gentamicina para eliminar o crescimento bacteriano extracelular. Após $1 \mathrm{~h}$, o meio contendo gentamicina foi removido e deu-se início a contagem do tempo pós infecção. Após 2, 6 e 24 h pós infecção, as células foram lisadas com $1 \mathrm{~mL}$ de água estéril, diluídas em meio LB e plaqueadas em placa contendo LB ágar em estufa sem $\mathrm{CO}_{2}$ a $37^{\circ} \mathrm{C}$ por $18 \mathrm{~h}$, para a determinação do número de unidades formadoras de colônias (UFC).

\subsection{Análise Estatística}

Todas as análises estatísticas foram realizadas com o auxílio de um software computacional chamado Graphpad Prism, da companhia Graphpad Software Incorporation, versão 3.02. O teste usado foi o ANOVA, seguido pelo teste Bonferroni. Valores de $p<0,01$ e $p<0,05$ foram considerados estatisticamente significativos. 
4 RESULTADOS 


\subsection{Macrófagos peritoneais são permissivos à replicação de Salmonella typhimurium deficiente em flagelina que falha em induzir piroptose}

Bactérias patogênicas como S. typhimurium e L. pneumophila infectam as células hospedeiras e modulam o seu nicho intracelular através da liberação de proteínas bacterianas no citosol por sistemas de secreção, como o sistema do tipo III, presente em S. typhimurium e do tipo IV presente em L. pneumophila. A flagelina, o componente principal do filamento flagelar destas bactérias, pode ser liberada no citosol celular onde é capaz de ativar os inflamassomas, NLRC4 e NAIP5 e induzir a morte da célula infectada por piroptose (Franchi et al., 2006; Zamboni et al., 2006). A morte do macrófago por piroptose como resultado desse reconhecimento tem sido postulada como um mecanismo de controle da infecção, uma vez que promove a perda do nicho intracelular importante para a replicação da bactéria e a liberação de citocinas inflamatórias com grande papel na infecção.

Para iniciar a avaliação da dependência da flagelina para a indução do processo de morte celular, bem como, para a habilidade do macrófago em conter a infecção, macrófagos peritoneais de animais C57BL/6 foram infectados com a bactéria S. typhimurium LT21412 (selvagem) e S. typhimurium LT22157 (sem flagelina). Nós observamos que a ausência do reconhecimento da flagelina parece tornar o macrófago mais susceptível à infecção, uma vez que os macrófagos infectados pela bactéria mutante apresentaram carga bacteriana maior se comparados aos estimulados com a S. typhimurium selvagem (Fig. 3A).

Além disso, nossos resultados ainda demonstram claramente que apenas a infecção pela bactéria selvagem foi capaz de levar o macrófago infectado à morte, 6 $\mathrm{h}$ após o estímulo, enquanto a bactéria mutante que não expressa flagelina falhou completamente em induzir morte celular, confirmando a importância do reconhecimento deste agonista para a indução de morte do macrofago infectado (Fig. 3B). Dessa maneira, nossos resultados sugerem que o processo de morte celular dependente do reconhecimento da flagelina pode ser, de fato, um importante mecanismo através do qual a imunidade inata contém a infecção por $S$. typhimurium. 


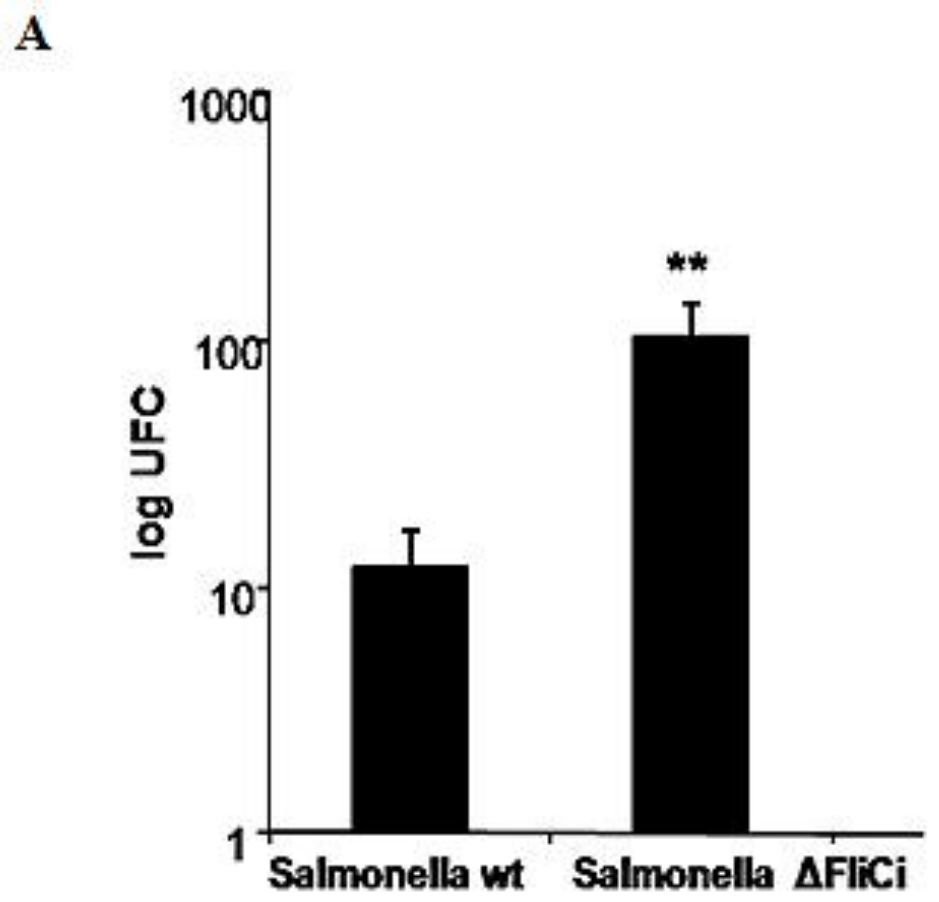

B

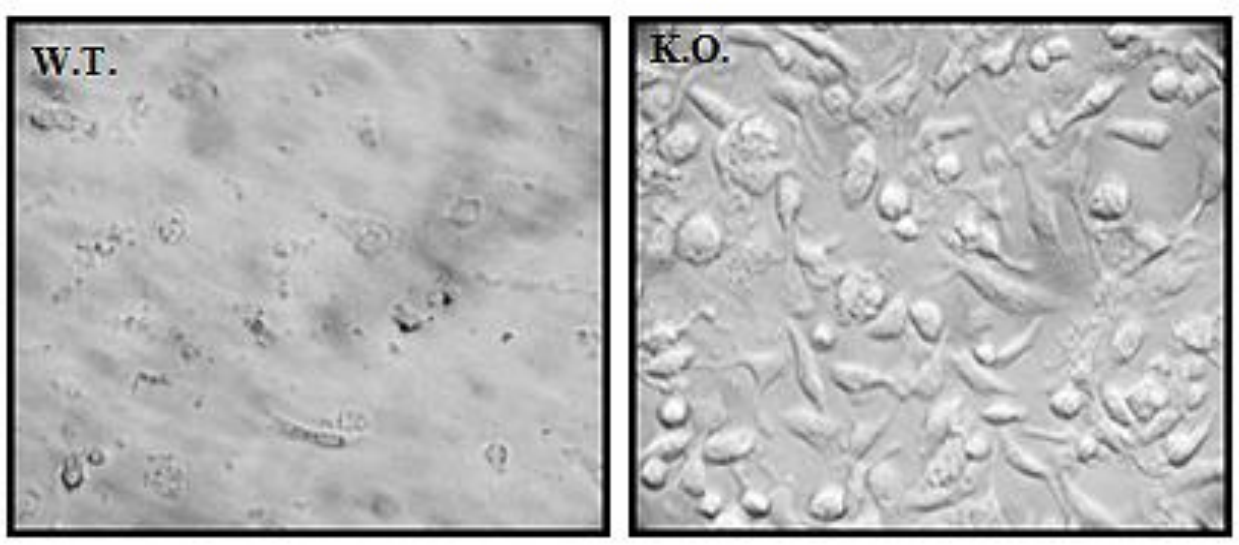

Figura 3. S. typhimurium selvagem expressando flagelina leva à morte do macrófago. Macrófagos peritoneais de animais C57BL/6 foram infectados com S. typhimurium LT21412 selvagem (WT) ou S. typhimurium LT22157 mutante, deficiente em flagelina $(\triangle \mathrm{FliCi})$, no $\mathrm{MOI} 1: 10$. (A) O número de unidades formadoras de colônias bacterianas (UFC) foi determinado $2 \mathrm{~h}$ após a infecção. Os dados representam média entre duplicatas. (B) A verificação do efeito citotóxico foi realizada $6 \mathrm{~h}$ após infecção pela observação em microscópio óptico de contraste de fase. As fotografias representam aumento de $400 \mathrm{X}$. 


\subsection{As flagelinas purificadas de Bacillus subtilis e Salmonella typhimurium modulam de maneira distinta a ativação do macrófago}

A flagelina pode ser reconhecida tanto pelo receptor transmembrânico TLR5 quanto pelos membros dos receptores citosólicos NLR: NLRC4 e NAIP5 (Iwasaki e Medzhitov, 2004; Franchi et al., 2006; Molofsky et al., 2006; Zamboni et al., 2006; Lightfield et al., 2008). Entretanto, o mecanismo exato pelo qual a flagelina é reconhecida e os fenômenos decorrentes desse reconhecimento ainda não estão completamente elucidados. Uma vez que grande parte dos estudos aborda o papel desses receptores utilizando o microorganismo inteiro, pouco se conhece sobre o papel individual desses na ativação dos macrófagos e na indução do processo de morte celular a partir do reconhecimento da flagelina.

$\mathrm{Na}$ tentativa de elucidar esses aspectos, macrófagos peritoneais foram estimulados com a flagelina purificada das bactérias gram-positiva $B$. subtilis (FLAB.S) e gram-negativa $S$. typhimurium (FliCi) em sua forma livre que permite seu reconhecimento extracelular pelo receptor TLR5, ou inserida no DOTAP, uma vesícula lipídica catiônica que permite a entrega desse agonista no citosol celular e a consequente ativação dos NLRs (FLA-B.SDot e FliCiDot), como descrito anteriormente por nosso grupo (Buzzo et al., 2010).

Recentemente foi demonstrado que apenas 35 aminoácidos pertencentes ao domínio C-terminal da estrutura das flagelinas de L. pneumophila e $S$. typhimurium, são responsáveis pelo reconhecimento deste agonista pelos receptores citosólicos NLRC4 e NAIP5 e a consequente indução de morte do macrófago por piroptose (Lightfield et al., 2008). Esta região da estrutura da flagelina se mantém altamente conservada para diferentes espécies bacterianas, incluindo a flagelina de $B$. subtilis (Fig. 4A). Uma vez que a flagelina de $B$. subtilis possui 275 aminoácidos em toda a sua estrutura linear, enquanto a flagelina da $S$. typhimurium possui 495 aminoácidos em toda a sua estrutura, para a realização dos experimentos, as diferentes flagelinas foram ajustadas para a mesma concentração molar, como descrito em Material e Métodos. 
Nós observamos que, após 6 h de estímulo, ambas as flagelinas citosólicas de $B$. subtilis e $S$. typhimurium foram capazes de induzir secreção de IL-1 $\beta$ de maneira dose dependente (Fig. 4B e C), embora a flagelina citosólica de $S$. typhimurium tenha induzido níveis aproximadamente duas vezes mais elevados de IL-1 $\beta$ do que a flagelina de $B$. subtilis, na mesma concentração molar. Surpreendentemente, ao contrário da flagelina de $B$. subtilis, a flagelina purificada de S. typhimurium em sua forma livre, foi capaz de induzir liberação da citocina IL-1 $\beta$ (Fig. 4B) em níveis comparáveis aos da flagelina citosólica. Em contrapartida, somente as flagelinas em sua forma livre induziram produção de IL-6, indicativo da ativação de TLR5 pelo reconhecimento extracelular da flagelina (Fig. 4D). A ausência de IL-6 em resposta às flagelinas citosólicas (Fig. 4E) é um excelente controle da nossa ferramenta experimental, pois descarta a possibilidade de que haja influência de reconhecimento do TLR5 por algum resquício do agonista livre durante a preparação das flagelinas inseridas no DOTAP.

A produção de $\mathrm{IL}-1 \beta$ em resposta às flagelinas citosólicas mostrou ser um fenômeno dependente de caspase-1 após ativação pelo inflamassoma NLRC4 (Fig. $5 \mathrm{~A}$ e B). $O$ fato da flagelina purificada de $S$. typhimurium em sua forma livre induzir liberação de IL-1 $\beta$, sugere que esta flagelina, ao contrário da flagelina de $B$. subtilis, possui a habilidade de alcançar o citosol celular e induzir ativação de caspase-1. De acordo com isso, nossos dados também demonstram que a produção de IL-1 $\beta$ induzida pela flagelina de $S$. typhimurium em sua forma livre é totalmente dependente da atividade do eixo NLRC4-caspase-1, uma vez que sua produção é abolida nas células provenientes de animais deficientes nestas moléculas (Fig. 5A), sugerindo que a produção de IL-1 $\beta$ induzida pela flagelina livre de $S$. typhimurium é um reflexo da ativação do inflamassoma e da caspase-1, no citosol celular. 


\section{B. subtilis :}

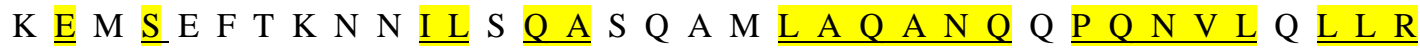

\section{S. typhimurium:}

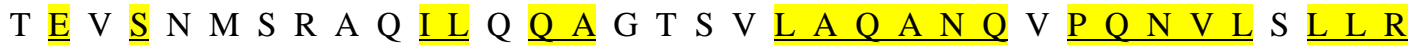

B

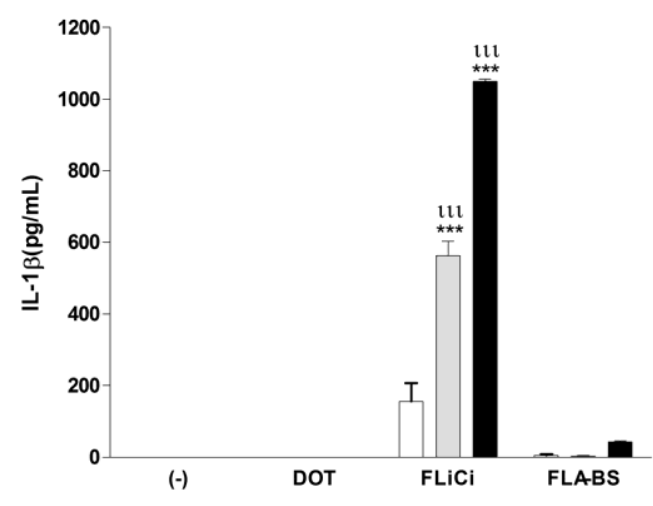

D

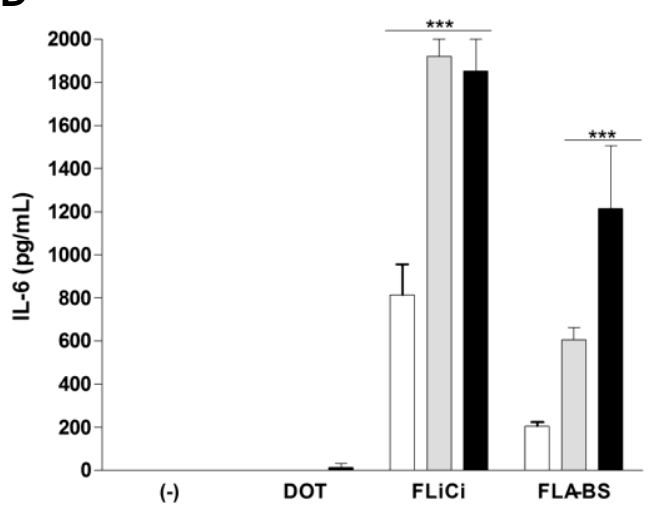

C

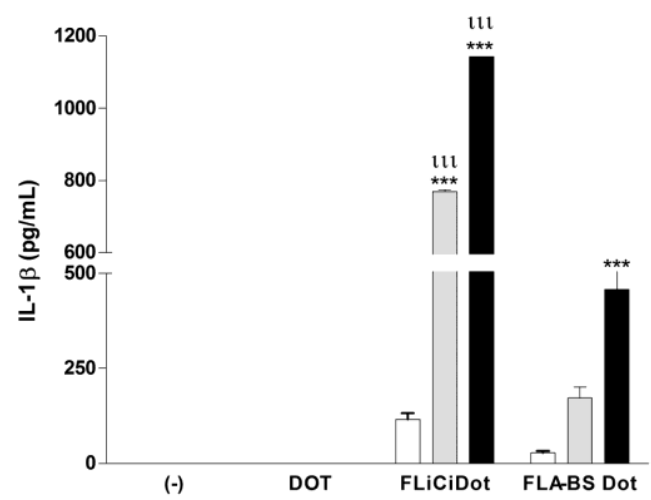

E

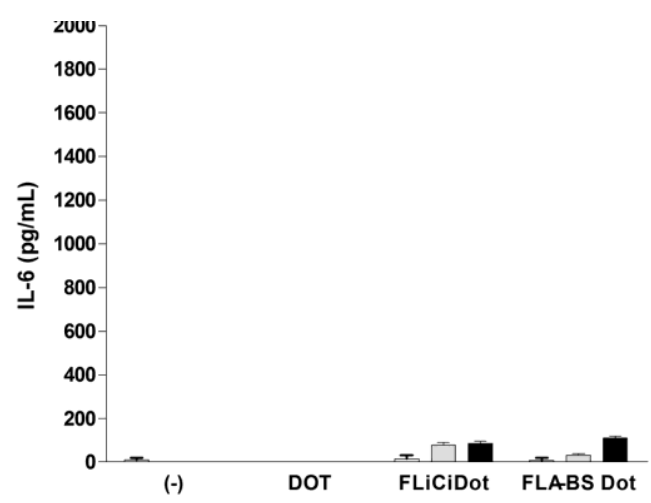

\section{$\square 1.3 \times 10^{-10} \mathrm{M} \square 4 \times 10^{-10} \mathrm{M} \square 8 \times 10^{-10} \mathrm{M}$}

Figura 4. Flagelinas purificadas de S. typhimurium e B. subtilis ativam o macrófago de maneira distinta. (A) Figura representativa da região C-terminal conservada das flagelinas de $B$. subtilis e $S$. typhimurium. Macrófagos peritoneais de camundongos da linhagem C57BL/6 $\left(10^{5} / 200 \mu l\right)$ foram estimulados, in vitro, com flagelinas purificadas das bactérias $S$. typhimurium ou $B$. subtilis $\left(1,4\right.$ ou $8 \times 10^{-10}$ $M$ ), em sua forma livre (FliCi e FLA-B.S respectivamente) ou inseridas no DOTAP uma vesícula lipídica que permite a entrega deste agonista no citosol celular (FliCiDot e FLA-B.SDot, respectivamente). A liberação das citocinas IL-1 $\beta$ (B)(C) e IL-6 (D)(E) foi determinada no sobrenadante da cultura celular, após $6 \mathrm{~h}$ de estímulo, por ELISA. Os números representam a média \pm SD de amostras em duplicata. ${ }^{* * *} p<0,001$ quando comparado ao grupo controle e 1 $p<0,001$ quando 
comparado às doses inferiores de estímulo. Os dados são representativos de três experimentos independentes.
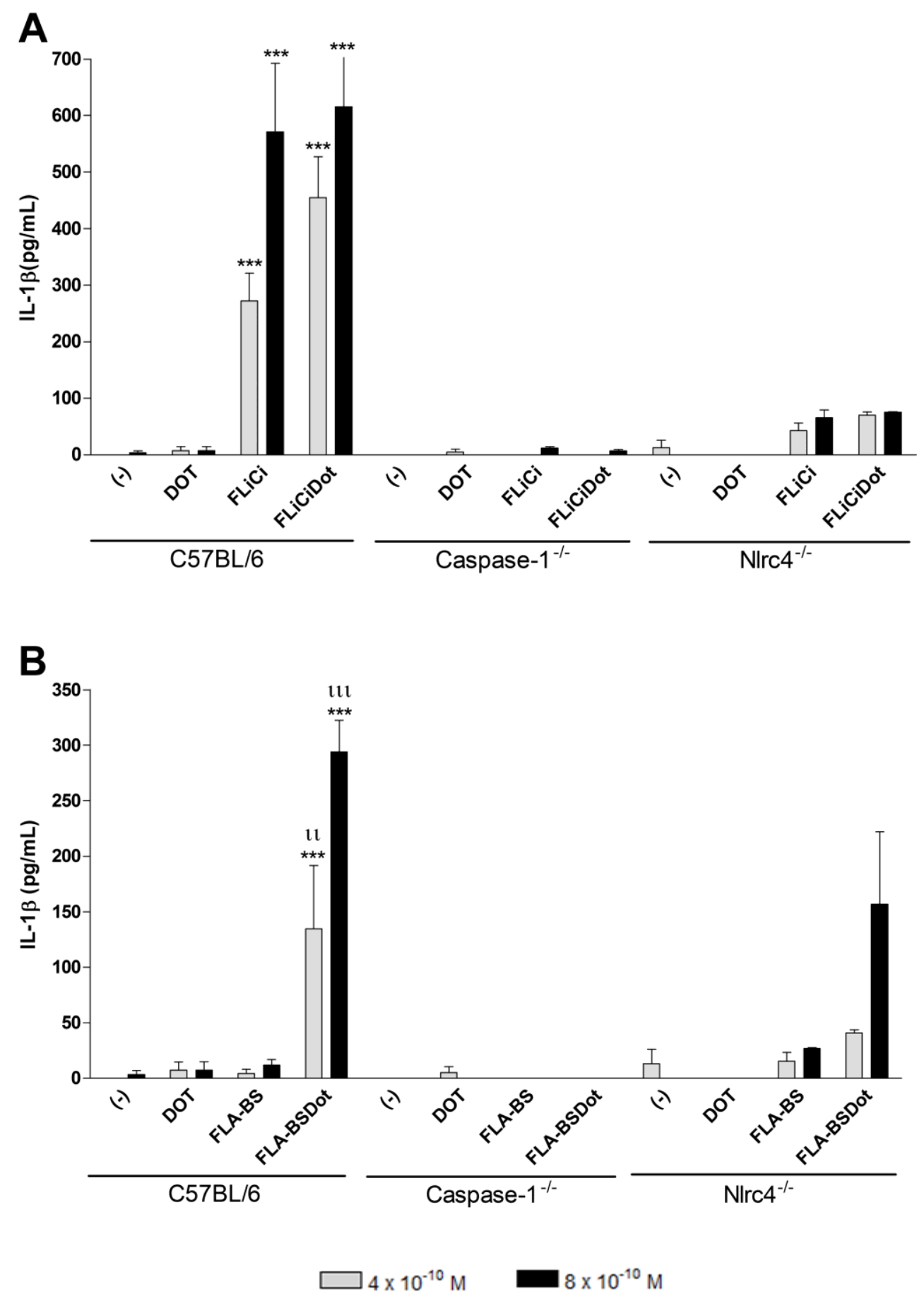

Figura 5. A liberação de IL-1 $\beta$ em resposta ao estímulo com flagelina é exclusivamente dependente de NLRC4 e caspase-1. Macrófagos peritoneais de camundongos da linhagem C57BL/6 (selvagem) ou deficiente nas moléculas Caspase-1 e NLRC4 $\left(10^{5} / 200 \mu \mathrm{l}\right)$ foram estimulados, in vitro, com flagelina purificada de $S$. typhimurium ou $B$. subtilis ( 4 ou $8 \times 10^{-10} \mathrm{M}$ ) em sua forma livre (FliCi e FLA-BS, respectivamente) ou inserida no DOTAP (FliCiDot e FLA-BSDot, respectivamente). A liberação de $\mathrm{IL}-1 \beta$ foi determinada no sobrenadante da 
cultura celular, após $6 \mathrm{~h}$ de estímulo, por ELISA. Os números representam a média \pm SD de amostras em duplicata. (A) ${ }^{* * *} p<0,001$ quando comparado aos grupos FliCi e FliCiDot dos animais deficientes. (B) ${ }^{* * *} p<0,001$ quando comparado ao grupo FLA-B.SDot/Caspase- $1^{-1}$ e ul ou u $p<0,001$ quando comparado ao grupo FLA-B.SDot/NIrc4 ${ }^{-/}$.

Para avaliar o processo de morte celular após estímulo por flagelina, nós utilizamos duas técnicas. A quantificação da enzima citosólica lactato dehidrogenase (LDH) no sobrenadante da cultura, método que vem sendo amplamente empregado na literatura como um meio de estimar o número de células não viáveis presentes em uma amostra, e o ensaio de viabilidade celular por MTT. O MTT (do inglês, 3[4,5-dimethylthiazol-2-yl]-2,5-diphenyltetrazolium bromide) é um sal tetrazólico, solúvel em água, que é convertido em formazan insolúvel, de coloração roxa, por clivagem do anel tetrazólico pela enzima succinato deidrogenase, no interior da mitocôndria. O produto formazan é impermeável às membranas celulares e, dessa maneira, se acumula no interior das células vivas. Assim, podemos avaliar através de porcentagem sobre um controle não estimulado o efeito tóxico induzido pelo estímulo com flagelina.

Nós observamos que, após 6 h de estímulo, ambas as flagelinas citosólicas de $B$. subtilis e $S$. typhimurium foram igualmente capazes de induzir liberação de LDH e citotoxicidade por MTT de maneira dose-dependente (Fig. 6C e D). Surpreendentemente, assim como foi observado anteriormente para a produção de IL-1 $\beta$, a flagelina purificada de $S$. typhimurium em sua forma livre, foi capaz de induzir liberação de LDH (Fig. 6A), ao contrário da flagelina de B. subtilis, que, mesmo em altas concentrações não induz morte celular. Entretanto, apesar de induzir altos níveis de LDH em $6 \mathrm{~h}$ de estímulo, a flagelina de $S$. typhimurium em sua forma livre não apresenta efeito tóxico significativo pelo MTT (Fig. 6B), o que sugere que a liberação de LDH e a morte do macrófago são fenômenos distintos, que podem, ou não, ocorrer simultaneamente, embora a liberação de LDH seja um forte indício de que a célula está em processo de morte, uma vez que houve perda da integridade da membrana plasmática.

Desta maneira, através de um modelo experimental utilizando um único agonista purificado, o que torna possível eliminar outros padrões moleculares bacterianos como o LPS, demonstramos que o reconhecimento da flagelina nos 
compartimentos extra e intracelular induzem distintas respostas efetoras dos macrófagos. Ainda, a flagelina de $S$. typhimurium apresenta maior potencial em induzir a produção de citocinas por macrófagos, IL-6 em sua forma livre e IL-1 $\beta$ em sua forma citosólica, além de apresentar potencial único de alcançar o citosol celular na ausência de vesículas de transfecção. Dessa maneira, apesar de ter sido descrito que as porções da estrutura da flagelina responsáveis pelo reconhecimento do receptor TLR5 e dos receptores citosólicos NLRC4 e NAIP5 se mantêm conservadas entre flagelinas de diferentes espécies de bactérias móveis (Lightfield et al., 2008), nós demonstramos que as flagelinas purificadas de $B$. subtilis e $S$. typhimurium modulam de maneira distinta a ativação do macrófago.
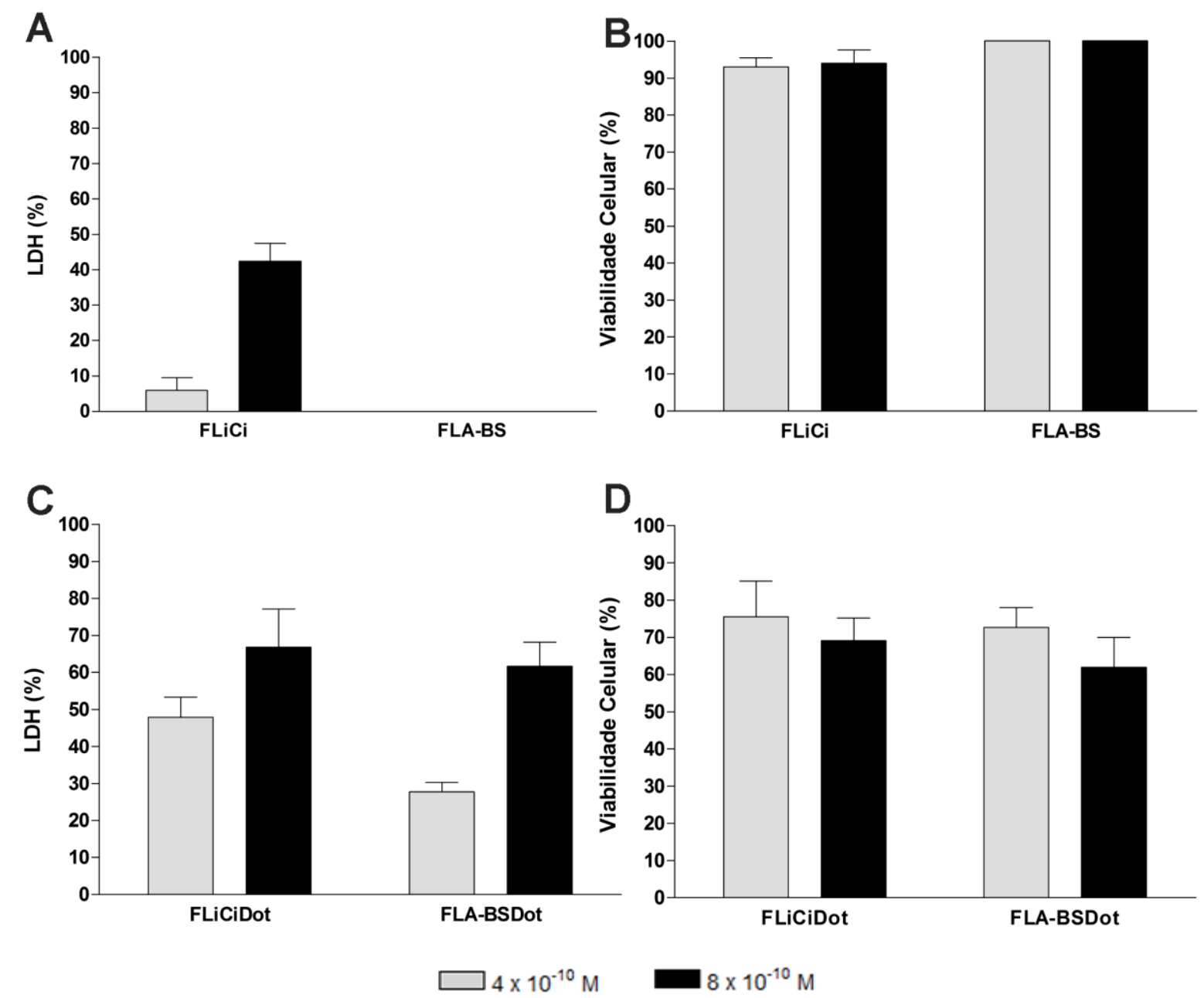

$8 \times 10^{-10} \mathrm{M}$

Figura 6. Flagelinas purificadas de S. typhimurium e B. subitilis em sua forma livre induzem toxicidade de maneira distinta. Macrófagos peritoneais de camundongos da linhagem C57BL/6 $\left(10^{5} / 200 \mu \mathrm{l}\right)$ foram estimulados, in vitro, com flagelinas purificadas das bactérias $S$. typhimurium ou $B$. subtilis (4 ou $8 x$ $10^{-10} \mathrm{M}$ ), em sua forma livre (FliCi e FLA-B.S respectivamente) ou inseridas no 
DOTAP uma vesícula lipídica que permite a entrega deste agonista no citosol celular (FliCiDot e FLA-B.SDot, respectivamente). A liberação de LDH pelos macrófagos estimulados foi avaliada na cultura celular como indicativo de perda da integridade da membrana plasmática $(\mathbf{A})(\mathbf{C})$ e o ensaio de MTT foi realizado para verificação da viabilidade celular (B)(D), ambos $6 \mathrm{~h}$ após o estímulo. Os números representam a média \pm SD de amostras em duplicata. Os dados são média de dois experimentos independentes.

\subsection{Flagelina citosólica induz morte celular de maneira independente da protease caspase-1 e do inflamassoma NLRC4}

Nas seções anteriores, nós mostramos que a liberação de IL-1ß e a morte celular induzidos por flagelina, são eventos que ocorrem somente quando o agonista alcança o citosol celular, seja naturalmente ou por meio de vesículas de transfecção. Uma vez que a liberação de IL-1 $\beta$ se mostrou completamente dependente do eixo NLRC4-caspase-1, o próximo passo foi investigar o envolvimento da protease caspase-1 e do inflamassoma NLRC4 na morte celular induzida pelas flagelinas citosólicas de $B$. subtilis e $S$. typhimurium. Para isso, quantificamos a viabilidade celular por MTT após 6 h e 24 h de estímulo.

Nós observamos que, mesmo após $24 \mathrm{~h}$ de estímulo, somente a flagelina citosólica de $B$. subtilis é capaz de produzir efeito tóxico nos macrófagos, e não a flagelina em sua forma livre, conforme observado anteriormente, confirmando que somente o reconhecimento desse agonista no citosol celular, e não seu reconhecimento extracelular, leva os macrófagos estimulados à morte (Fig. 7A). Ao contrário da flagelina de $B$. subtilis, a flagelina de $S$. typhimurium em sua forma livre induz morte do macrófago após $24 \mathrm{~h}$ de estímulo, de maneira dependente de caspase-1 e do inflamassoma NLRC4 (Fig. 8B), indicando que a morte induzida pela flagelina livre de $S$. typhimurium, assim com foi observado para a liberação de IL-1 $\beta$, é um reflexo da ativação de caspase-1 após engajamento com o inflamassoma NLRC4 no citosol celular.

Nós também observamos que, após 6 h de estímulo por flagelina citosólica, as células dos animais deficientes em caspase-1 estão mais viáveis do que as células provenientes dos animais selvagens (Fig. 7B e 8A). Entretanto, especialmente na maior concentração de flagelina, já podemos observar um efeito tóxico de aproximadamente $30-40 \%$ nas células deficientes em caspase-1 (Fig. 7B e 
8A). Após $24 \mathrm{~h}$ de estímulo, tanto as células provenientes de animais selvagens quanto as células de animais deficientes em caspase-1 são igualmente susceptíveis ao efeito tóxico induzido pelas flagelinas citosólicas de $B$. subtilis e S.typhimurium, demonstrando que a morte induzida por flagelina citosólica ocorre na ausência da protease caspase-1 (Fig. 7C e 8B).

Já os macrófagos de animais deficientes no inflamassoma NLRC4, parecem ser menos susceptíveis à morte celular no tempo de $6 \mathrm{~h}$, do que as células deficientes em caspase-1 (Fig. 7B e 8A), porém, também sofrem morte celular em tempo mais tardio, com porcentagens bem próximas às apresentadas pelas células dos animais selvagens (Fig. 7C e 8B). Juntos, nossos resultados sugerem que a caspase-1 seja responsável por algumas características funcionais decorrentes do reconhecimento da flagelina citosólica, como a produção de IL-1 $\beta$, porém, ao contrário do que prevê a literatura atual, a morte celular em resposta à flagelina acontece na ausência dessa protease. 


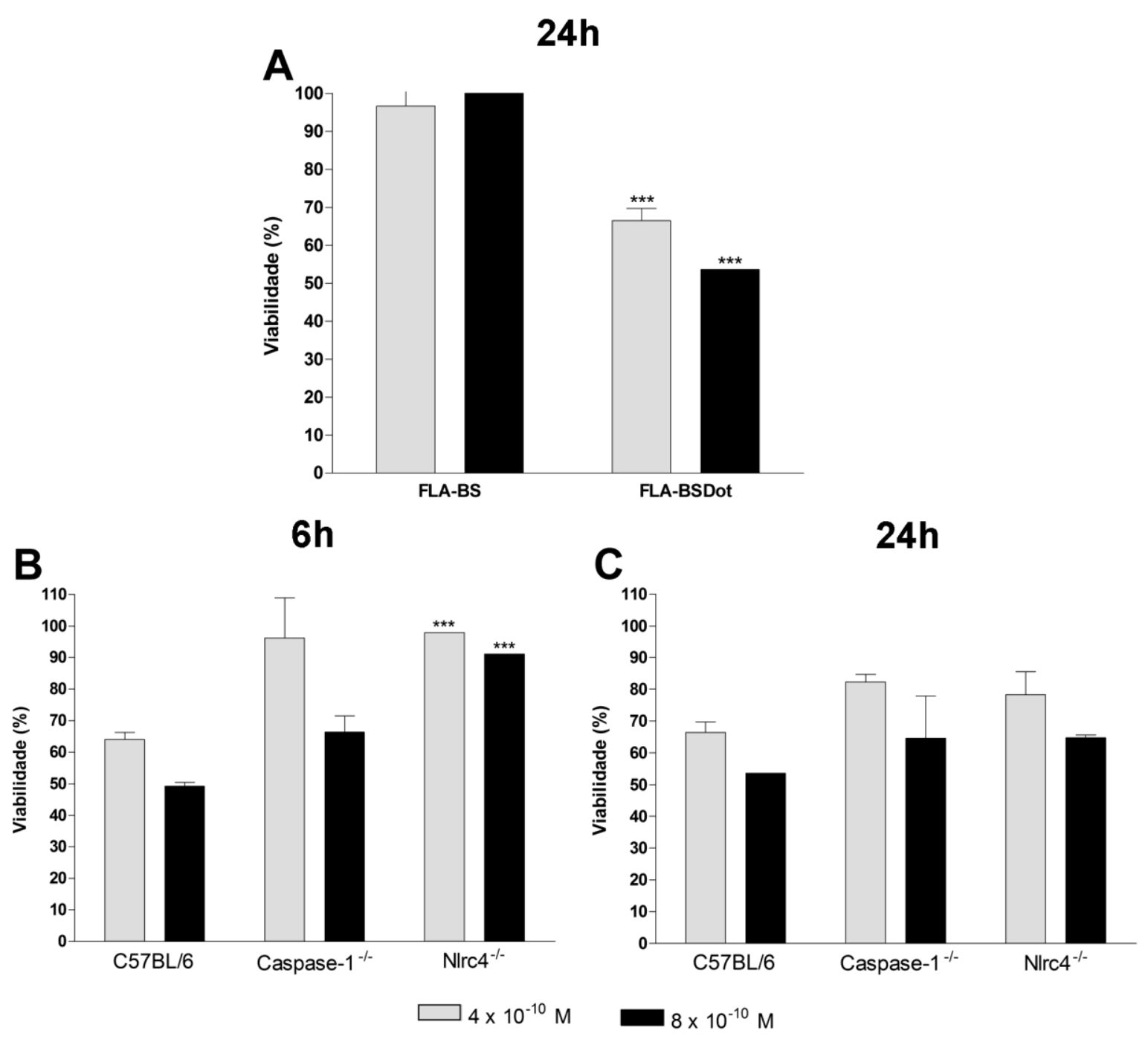

Figura 7. Flagelina citosólica de $B$. subtilis induz morte do macrófago de maneira independente de caspase-1 e do inflamassoma NLRC4. Macrófagos peritoneais de camundongos da linhagem C57BL/6 (selvagem) ou deficiente nas moléculas Caspase-1 e NLRC4 $\left(10^{5} / 200 \mu l\right)$ foram estimulados in vitro, com flagelina purificada de $B$. subtilis (4 ou $8 \times 10^{-10} \mathrm{M}$ ) em sua forma livre (FLA-BS) (A) ou inserida no DOTAP, uma vesícula lipídica que permite a entrega deste agonista no citosol celular (FLA-B.SDot) (A-C). Após 6 (B) ou 24 h (A)(C) de estímulo, foi realizado ensaio de MTT para verificação da viabilidade celular. Os números representam a média $\pm \mathrm{SD}$ de amostras em duplicata. ${ }^{* * *} p<0,001$ quando comparado ao FLA-BS (A) $e^{* * *} p<0,001$ quando comparado ao animal selvagem. 


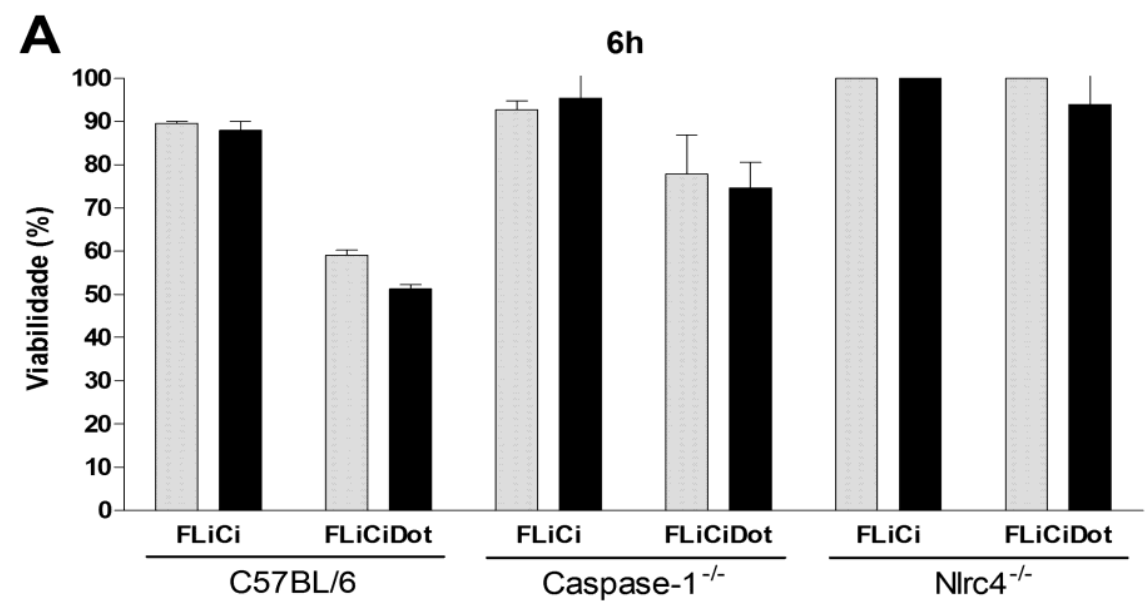

B

24h

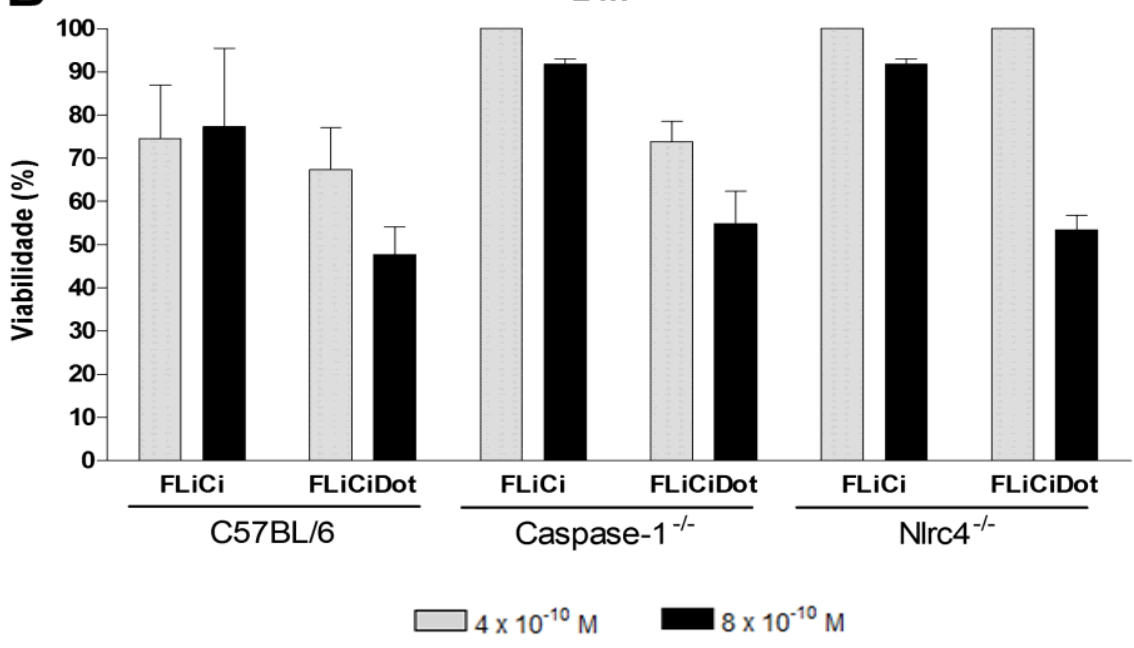

Figura 8. A morte do macrófago induzida por flagelina de S. typhimurium acontece na ausência de caspase-1. Macrófagos peritoneais de camundongos da linhagem C57BL/6 (selvagem) ou deficiente nas moléculas Caspase-1 e NLRC4 $\left(10^{5} / 200 \mu \mathrm{l}\right)$ foram estimulados in vitro com flagelina purificada de $S$. typhimurium (4 ou $8 \times 10^{-10} \mathrm{M}$ ) em sua forma livre (FliCi) ou inserida no DOTAP (FliCiDot). Após $6 \mathrm{~h}$ (A) ou $24 \mathrm{~h}$ (B) de estímulo, foi realizado ensaio de MTT para verificação da viabilidade celular. Os números representam a média \pm SD de amostras em duplicata. 


\subsection{Citotoxicidade induzida por flagelina citosólica de $B$. subtilis é independente da via de sinalização do TLR5}

Uma vez que a flagelina de $B$. subtillis se mostrou uma ferramenta adequada para discriminar a ativação induzida via TLR5 e inflamassomas, passamos a utilizar este agonista como ferramenta experimental para avaliar outros parâmetros do processo de morte celular induzido pela flagelina. Sabe-se que o reconhecimento extracelular da flagelina pelo TLR5 induz uma cascata de ativação celular dependente da molécula adaptadora MyD88 (Hayashi et al., 2001). Para investigar o envolvimento dessa molécula (e do TLR5) no processo de morte celular, macrófagos peritoneais de camundongos deficientes em MyD88 foram estimulados com a flagelina citosólica de B. subtilis. Nossos resultados demonstram que, mesmo em altas doses do agonista intracelular, os macrófagos de camundongos selvagens e deficientes em MyD88 foram igualmente susceptíveis à morte induzida pela flagelina citosólica (Fig. 9A e B), o que condiz com o reconhecimento deste agonista por receptores presentes no citosol celular que não se utilizam desta molécula para exercer suas funções. Além disso, estes dados descartam a possibilidade de que haja influência de reconhecimento do TLR5 por algum resquício do agonista livre durante a preparação da flagelina citosólica (FLA-B.SDot) no processo de morte celular observado. 


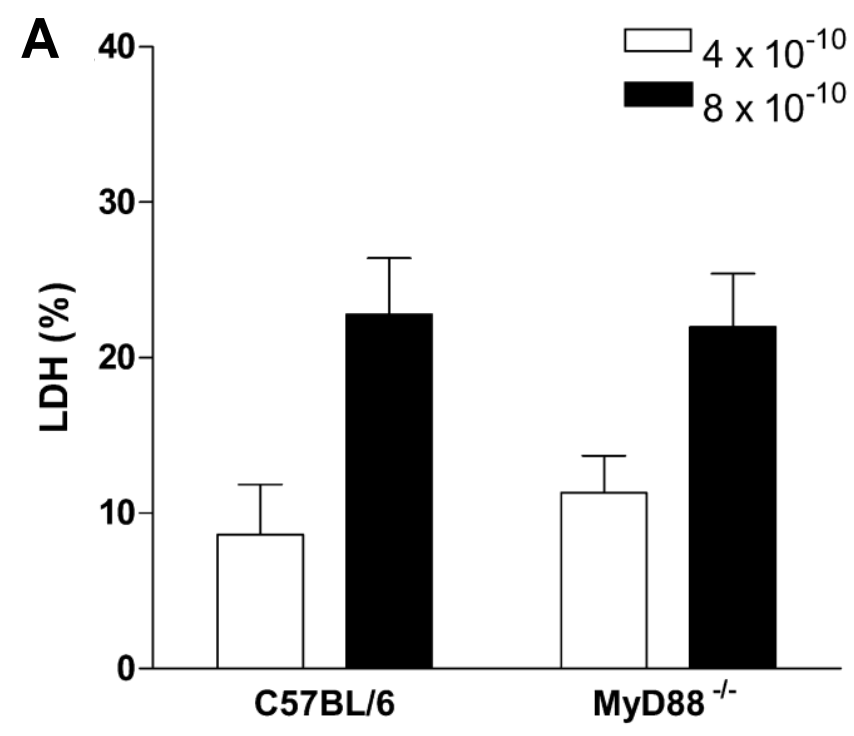

B
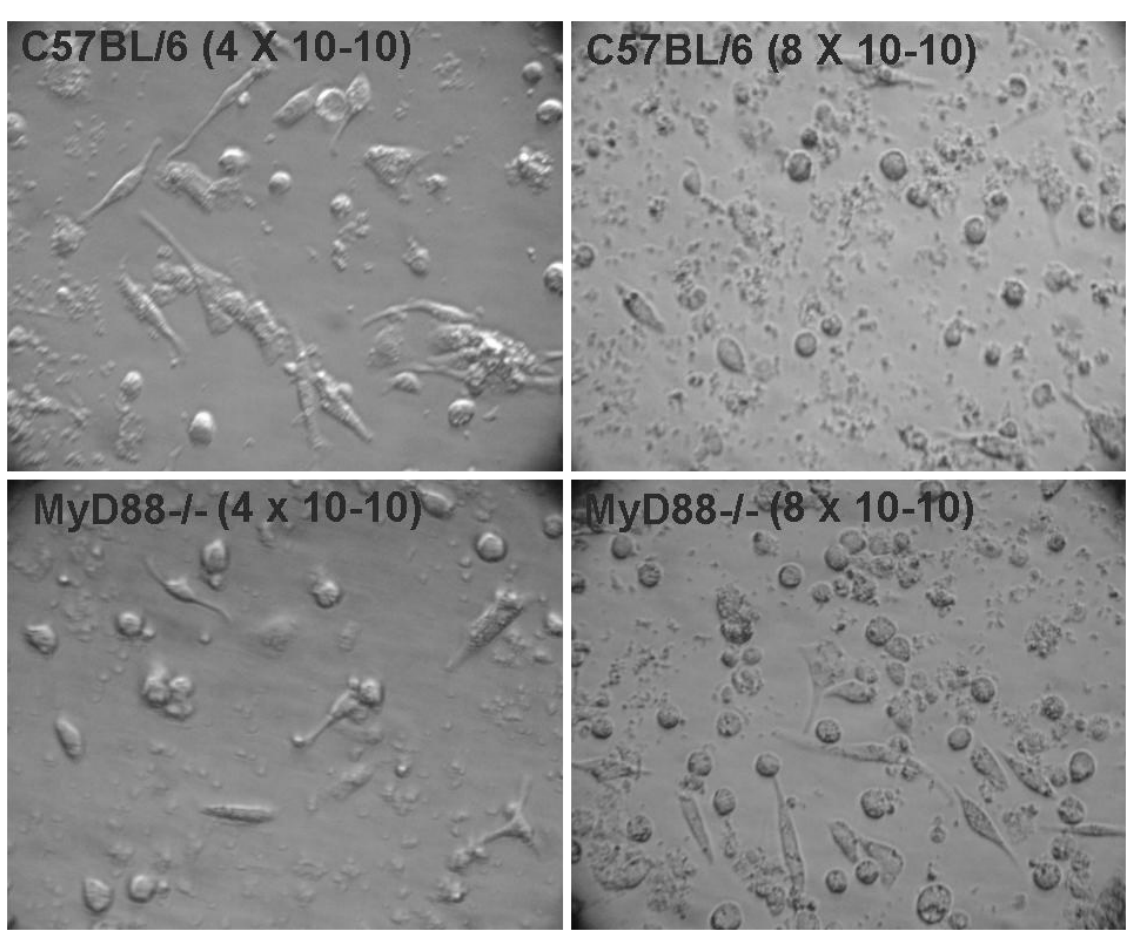

Figura 9. Morte celular induzida por flagelina citosólica é independente de MyD88. Macrófagos peritoneais de camundongos da linhagem C57BL/6 (selvagem) ou de animais knockouts para MyD88 $\left(10^{5} / 200 \mu \mathrm{l}\right)$ foram estimulados, in vitro, com $3 \mu \mathrm{g} / \mathrm{ml}\left(4 \times 10^{-10} \mathrm{M}\right)$ ou $6 \mu \mathrm{g} / \mathrm{ml}\left(8 \times 10^{-10} \mathrm{M}\right)$ de flagelina purificada de Bacillus subtilis inserida no DOTAP, uma vesícula lipídica catiônica que permite a entrega desse agonista no citosol celular (FLA-BSDot). (A) A quantidade de LDH liberada pelos macrófagos foi avaliada no sobrenadante da cultura celular, $6 \mathrm{~h}$ após estímulo (B). As fotografias representam ampliação original x 400 em microscópio óptico com contraste de fase. Os dados são representativos de dois experimentos independentes. 


\subsection{As citocinas liberadas por ação da caspase-1 não afetam a viabilidade do macrófago}

Uma vez que o processo de piroptose induzido pelo reconhecimento da flagelina citosólica pode ser acompanhado da liberação das citocinas próinflamatórias IL-1 $\beta$ e IL-18 (Martinon et al., 2002), para melhor caracterizar esse processo de morte celular precisávamos desvendar se essas citocinas poderiam, por si só, ter alguma participação na indução da morte das células estimuladas pela flagelina. Verificamos que a adição destas citocinas recombinantes à cultura celular, sozinhas ou juntas, em três diferentes concentrações (1, 5 e $10 \mathrm{ng} / \mathrm{ml})$, não foi capaz de induzir piroptose (Fig. 10), sugerindo que estas citocinas não induzem a morte celular observada no estímulo com a flagelina citosólica.

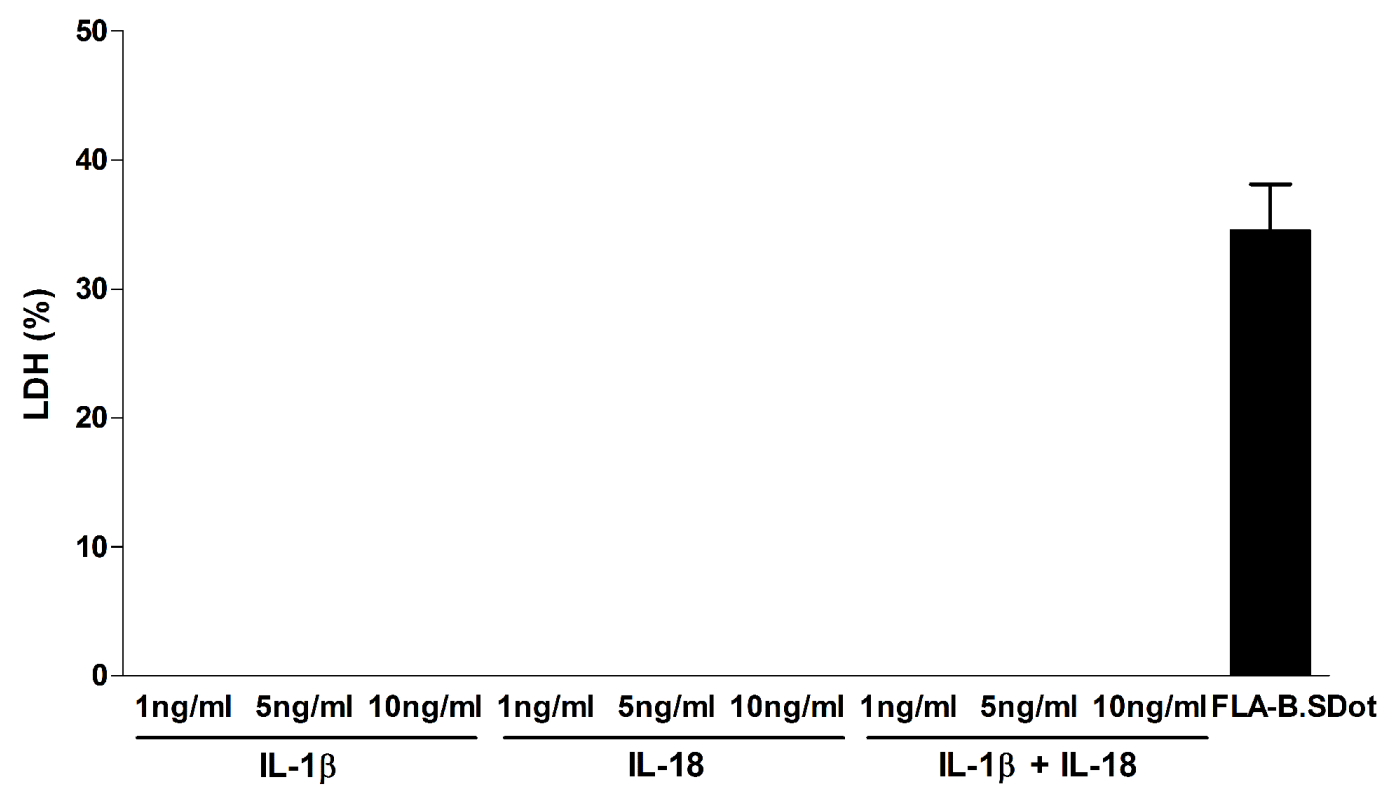

Figura 10. As citocinas IL-1 $\beta$ e IL-18 não induzem piroptose. Macrófagos peritoneais de camundongos da linhagem C57BL/6 $\left(10^{5} / 200 \mu \mathrm{l}\right)$ foram estimulados, in vitro, com 1,5 ou $10 \mathrm{ng} / \mathrm{ml}$ das citocinas IL-1 $\beta$, IL-18 ou ambas, ou com flagelina purificada de Bacillus subtilis inserida no DOTAP (FLA-BSDot). A quantidade de LDH liberada pelos macrófagos foi avaliada no sobrenadante da cultura celular, $6 \mathrm{~h}$ após infecção. 


\subsection{A formação de poros na membrana celular induzida por flagelina citosólica de $B$. subtilis precede a lise celular e a liberação de IL-1 $\beta$}

A morte celular por piroptose induzida em resposta à flagelina vem sendo descrita por um processo subseqüente à formação de poros na membrana plasmática de maneira dependente de caspase-1 (Silveira e Zamboni, 2010). Uma vez que a flagelina citosólica de $B$. subtilis induziu lise celular e liberação de IL-1 $\beta$, indicativo da ativação de caspase-1, nós investigamos a habilidade desse agonista em induzir a formação de poros na membrana plasmática. Para isso, estimulamos macrófagos peritoneais provenientes de animais C57BL/6 com flagelina purificada de $B$. subtilis em sua forma livre e citosólica e avaliamos a captação de brometo de etídio, um corante impermeável a membranas. Macrófagos com membrana celular intacta falham em internalizar brometo de etídio enquanto células contendo poros ou ruptura na membrana plasmática se tornam permeáveis a esse corante. Uma vez no interior da célula, o brometo intercala no DNA, proporcionando coloração vermelha ao núcleo celular (McGahon et al., 1995). O ensaio de formação de poros foi realizado pelo uso de brometo de etídio em combinação com laranja de acridina, um corante verde, acidofílico, e não-seletivo, que marca tanto células permeabilizadas quanto intactas (Zuckman et al., 1999).

Após $1 \mathrm{~h}$ de estímulo com flagelina citosólica, foi possível observar uma alta freqüência de células marcadas tanto com laranja de acridina como com brometo de etídio, indicativo da formação de poros na membrana celular, enquanto os macrófagos estimulados com flagelina livre apresentavam marcação semelhante ao controle não estimulado, contendo a grande maioria das células impermeáveis ao brometo (Fig. 11). Ainda, em 1,5 h de estímulo, já havia LDH no sobrenadante da cultura de macrófagos estimulados com flagelina citosólica (Fig. 12A) bem como, uma taxa já elevada de células positivas para brometo de etídio que não se coravam mais com laranja de acridina (Fig. 12B) sugerindo que não observamos mais a formação de poros na membrana celular neste tempo de estímulo, mas sim, a morte das células estimuladas com ruptura da membrana plasmática. Essa perda da integridade da membrana celular observada após estímulo com flagelina citosólica se mostrou acentuada após 3, 4 e $5 \mathrm{~h}$ de estímulo, e após 6 horas de estímulo quase $100 \%$ das células encontravam-se permeáveis ao brometo e não se coravam mais com laranja de acridina, o que indica que após esse período de tempo, as 
células começaram a sofrer um processo de ruptura total da membrana plasmática, e, portanto, não estavam mais viáveis.

Observamos ainda, que, a liberação de IL-1 $\beta$, correlaciona com o período de lise celular, e não com a formação de poros na membrana plasmática, uma vez que só a partir de $3 \mathrm{~h}$ de estímulo detectamos quantidades significativas da citocina IL$1 \beta$ no sobrenadante da cultura, sendo seu pico observado após $6 \mathrm{~h}$ de estímulo (Fig. 12C). Dessa maneira, nossos dados sugerem que a formação de poros na membrana plasmática é dependente do reconhecimento da flagelina de $B$. subitlis no citosol celular e culmina na posterior lise osmótica da célula, acompanhada da liberação de LDH e da citocina IL-1 $\beta$. 


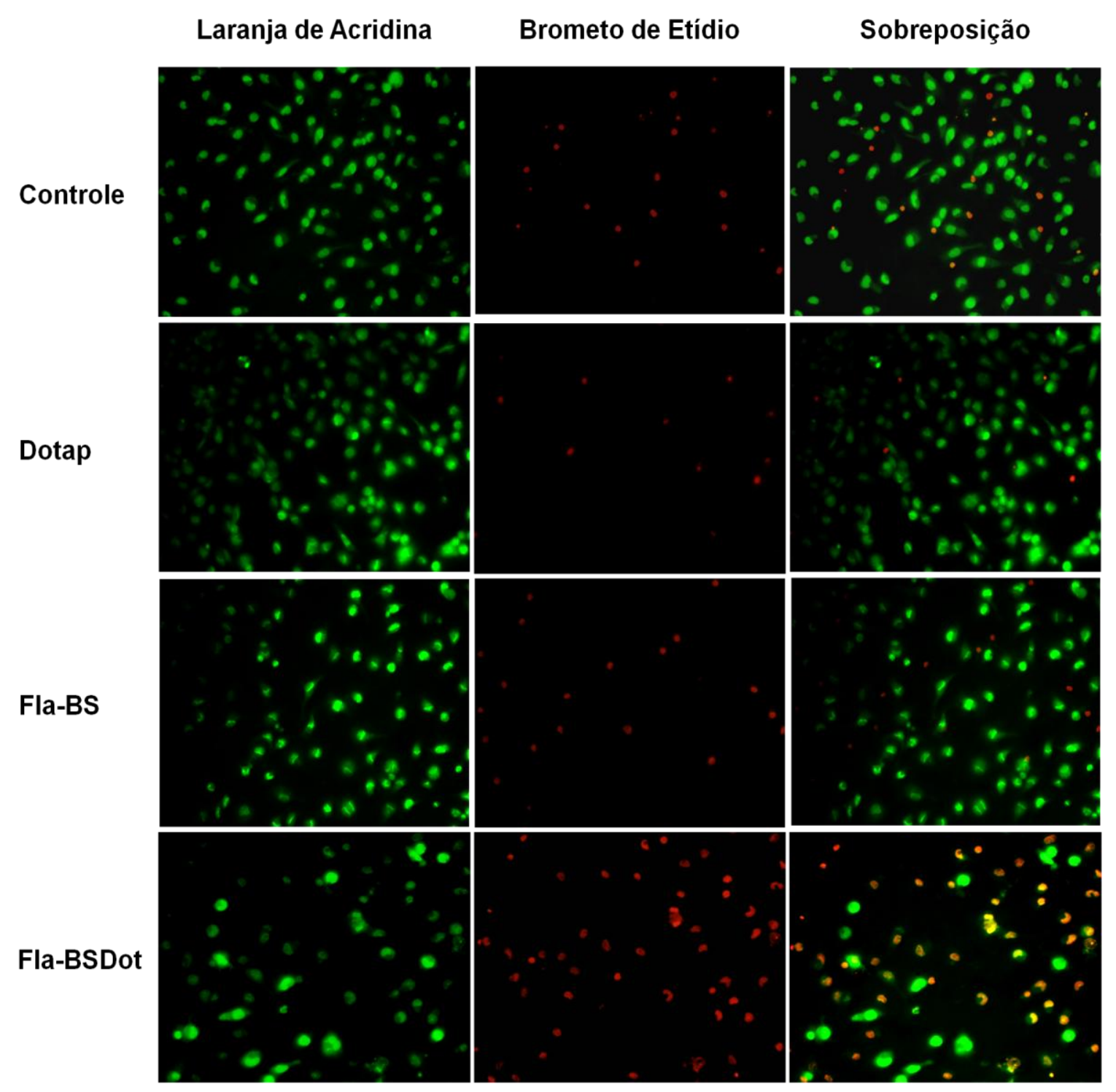

Figura 11. A transfecção da flagelina purificada de $B$. subtilis para o citosol celular induz a formação de poros na membrana plasmática. Macrófagos peritoneais de camundongos C57BL/6 $\left(10^{5} / 200 \mu \mathrm{l}\right)$ foram estimulados in vitro, com flagelina purificada de Bacillus subtilis na concentração de $8 \times 10^{-10} \mathrm{M}$, em sua forma livre (FLA-B.S) ou inserida no DOTAP, uma vesícula lipídica catiônica que permite a entrega desse agonista no citosol celular (FLA-BSDot). Após $1 \mathrm{~h}$ de estímulo, adicionou-se solução de PBS contendo Brometo de Etídio e Laranja de Acridina a $50 \mu \mathrm{g} / \mathrm{ml}(\mathrm{v} / \mathrm{v})$. Células coradas com Laranja de acridina (verde) indicam o total de células viáveis em cada campo, enquanto o Brometo de Etídio (vermelho) indica as células permeabilizadas que permitiram a difusão de brometo para o seu interior. Os painéis à direita indicam imagens sobrepostas. As fotografias representam ampliação original x 400 em microscópio de fluorescência. 
A

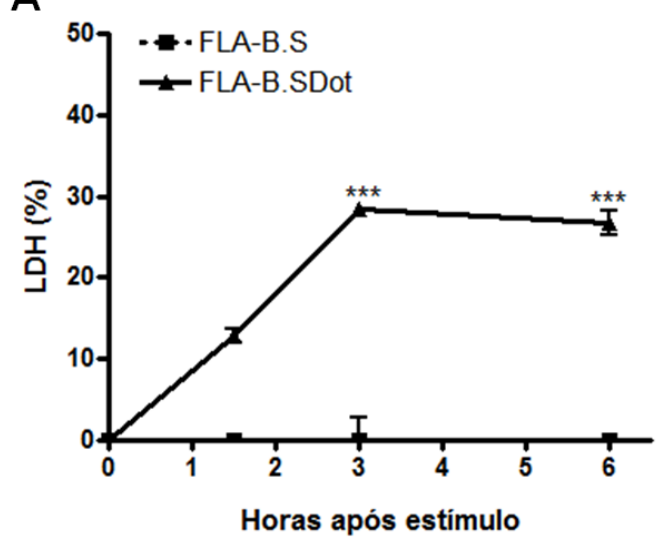

B

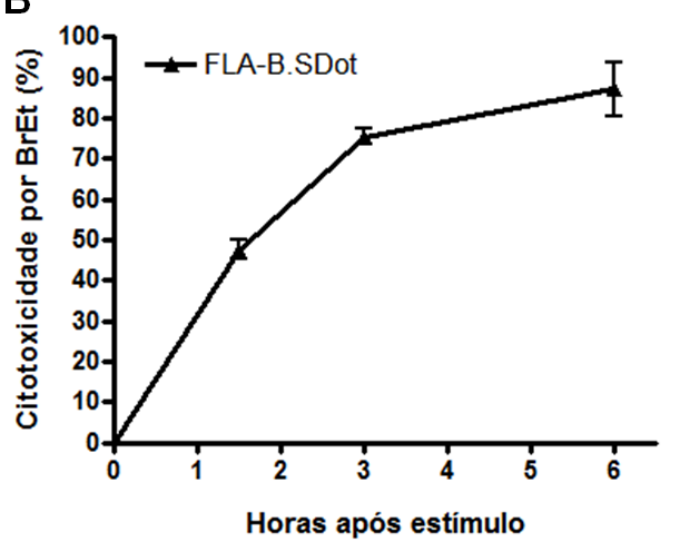

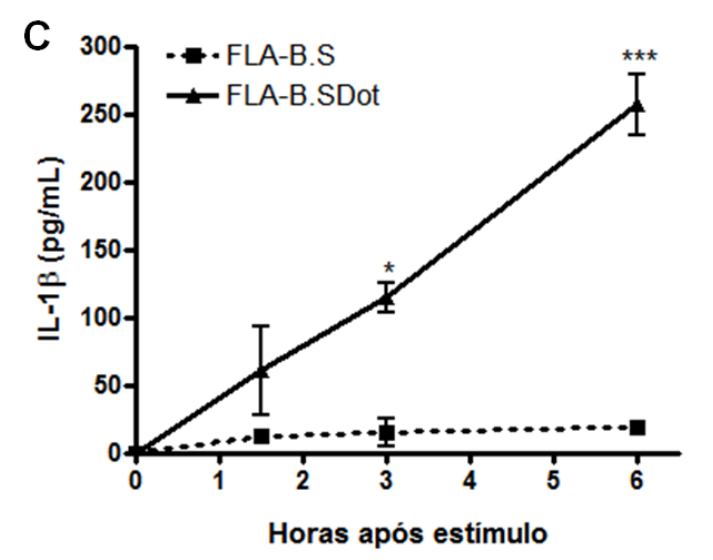

Figura 12. A formação de poros na membrana celular após estímulo com flagelina citosólica precede a liberação de IL-1ß e a lise celular. Macrófagos peritoneais de camundongos da linhagem C57BL/6 (selvagem) foram estimulados, in vitro, com flagelina purificada de $B$. subtilis $\left(8 \times 10^{-10} \mathrm{M}\right)$ em sua forma livre (FLA-B.S) ou inserida no DOTAP, uma vesícula lipídica que permite a entrega deste agonista no citosol celular (FLA-B.SDot). Após 1,5 h, 3 h e 6 h de estímulo, as culturas foram submetidas a ensaio de liberação de LDH (A) e de marcação com brometo de etídio e laranja de acridina (B). Após os mesmos tempos de estímulo, a liberação de IL-1 $\beta$ foi determinada no sobrenadante das culturas celulares por ELISA (C). ${ }^{* * *} p<0,001$ quando comparado ao grupo FLABS. Os dados foram obtidos das mesmas culturas. 


\subsection{Macrófagos deficientes em caspase-1 sofrem cinética de eventos semelhante aos macrófagos provenientes de animal selvagem}

Uma vez que demonstramos que a morte celular em reposta à flagelina acontece mesmo na ausência da caspase-1, a cinética de eventos induzidos pela flagelina citosólica também foi avaliada nos macrófagos provenientes de animais deficientes para esta protease. De fato, a liberação de LDH em reposta à flagelina citosólica acontece em tempos mais tardios na ausência de caspase-1 (Fig. 13A). Ainda, a liberação de IL-1 $\beta$ nos sobrenadantes da cultura de macrófagos estimulados com flagelina citosólica se mostrou completamente dependente da caspase-1, uma vez que, em nenhum dos tempos observados houve liberação desta citocina pelos macrófagos dos animais deficientes nesta molécula (Fig. 13B).

Após $1,5 \mathrm{~h}$ de estímulo com flagelina citosólica, não observamos células duplamente marcadas para laranja de acridina e brometo de etídio, ao contrário, observamos alta freqüência de células marcadas somente com brometo de etídio (Fig. 13C), acompanhada da liberação de LDH (Fig. 13A) tanto nos macrófagos dos animais selvagens quanto deficientes em caspase-1, embora estes últimos com cinética atrasada em relação aos primeiros. Em conjunto, nossos dados sugerem que a morte do macrófago após estímulo por flagelina citosólica é um processo resultante de uma cinética de eventos semelhantes na presença ou na ausência de caspase-1. Entretanto, embora a liberação de IL-1 $\beta$ em resposta à flagelina citosólica seja um fenômeno completamente dependente da presença de caspase-1 ativa, nossos dados deixam em aberto se a morte celular que ocorre na ausência de caspase-1 também é um fenômeno decorrente da formação de poros na membrana celular, assim como é observado na presença desta molécula. 

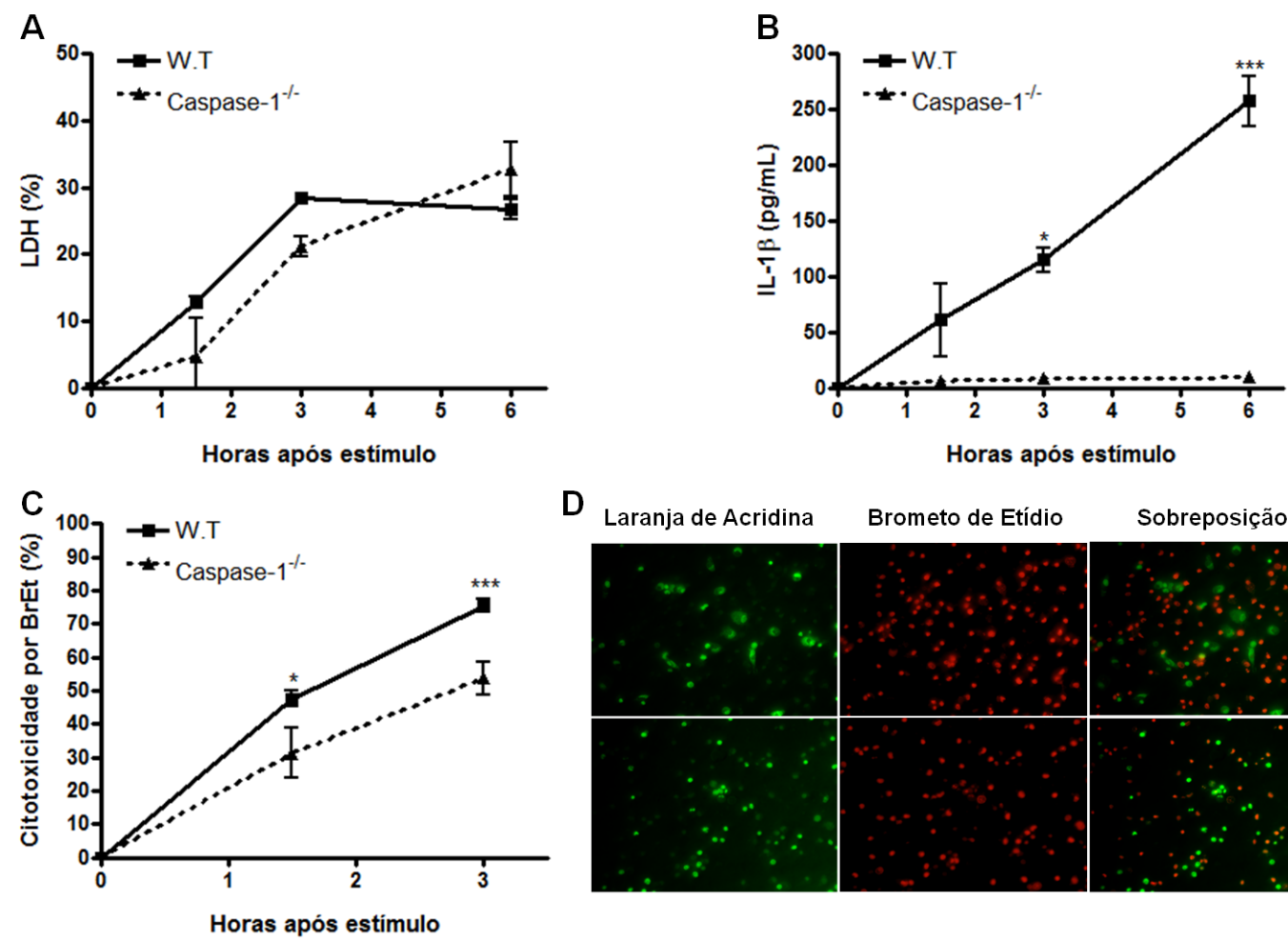

D Laranja de Acridina Brometo de Etídio Sobreposição

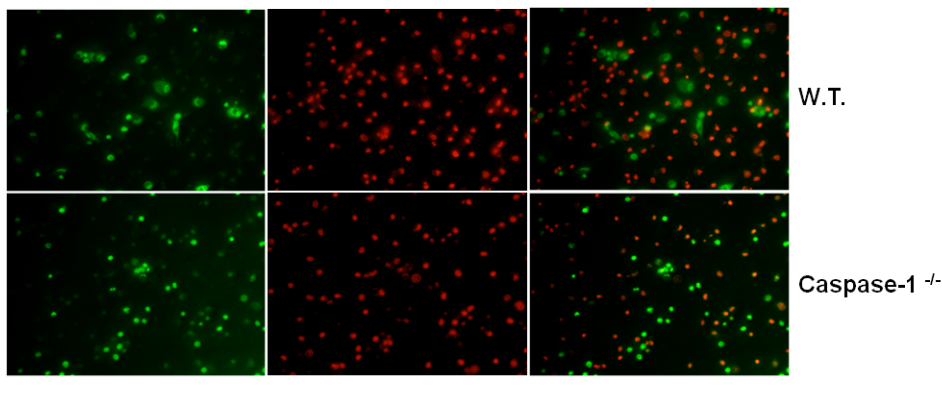

Figura 13. A liberação de IL-1 $\beta$ induzida por flagelina citosólica é um processo regulado pela caspase-1 e não está relacionado com a morte celular. Macrófagos peritoneais de camundongos da linhagem C57BL/6 (selvagem) ou deficientes na molécula Caspase-1 $\left(10^{5} / 200 \mu \mathrm{l}\right)$ foram estimulados, in vitro, com flagelina purificada de Bacillus subtilis $\left(8 \times 10^{-10} \mathrm{M}\right)$ inserida no DOTAP, uma vesícula lipídica que permite a entrega deste agonista no citosol celular (FLAB.SDot). Após $1,5 \mathrm{~h}, 3 \mathrm{~h}$ e $6 \mathrm{~h}$ de estímulo, as culturas foram submetidas a ensaio de liberação de $\operatorname{LDH}(\mathbf{A})$ e de marcação com brometo de etídio e laranja de acridina (C)(D). A liberação de IL-1 $\beta$ foi determinada no sobrenadante das culturas celulares por ELISA (B). ${ }^{* * *} p<0,001$ quando comparado ao grupo FLABSDot/caspase- $1^{-1-}$. Células coradas com Laranja de acridina (verde) indicam 0 total de células viáveis em cada campo, enquanto o Brometo de Etídio (vermelho) indica as células permeabilizadas que permitiram a difusão de brometo para o seu interior (D). Os painéis à direita indicam imagens sobrepostas. As fotografias representam ampliação original $x 400 \mathrm{em}$ microscópio de fluorescência. Os dados foram obtidos das mesmas culturas. 
A ativação da protease caspase-1 emergiu nos últimos anos como um importante fenômeno responsável por diferentes processos da célula incluindo secreção de citocinas pró-inflamatórias e resposta contra patógenos intracelulares (Bortoluci e Medzhitov, 2010). Embora pouco se saiba sobre os substratos celulares da caspase-1, é bem descrito na literatura que macrófagos expressando caspase-1 ativa liberam grandes quantidades de IL-1 $\beta$ e sofrem uma forma de morte celular não-convencional, a piroptose (Fink e Cookson, 2007). Assim, tem sido proposto um papel para a caspase-1 na defesa do hospedeiro frente a infecções por patógenos intracelulares. Esse papel no controle de patógenos tem sido atribuído, em grande parte, pela ação das citocinas pró-inflamatórias IL-1 $\beta$ e IL-18 que se tornam ativas e são liberadas somente após clivagem pela caspase-1. No entanto, ultimamente tem sido proposto um papel para a piroptose no controle de patógenos, uma vez que a morte do macrófago leva à destruição do nicho intracelular necessário para a replicação e disseminação do microorganismo, além de promover uma intensa resposta inflamatória devido à liberação do conteúdo intracelular (Bortoluci e Medzhitov, 2010). Entretanto, a regulação molecular desse processo de morte, bem como, a sua contribuição para o controle de infecções ainda não está completamente elucidado.

Recentemente, foi demonstrada a primeira evidência do papel da piroptose no controle de patógenos in vivo (Miao et al., 2010). Durante infecção por $S$. typhimurium expressando flagelina, a remoção da bactéria foi mediada pela via de detecção da flagelina citosólica, através da ativação de caspase-1 pelo inflamassoma NLRC4. Entretanto, o controle da infecção ocorreu independentemente das citocinas IL-1 $\beta$ e IL-18, uma vez que os animais deficientes em ambas citocinas ou seus receptores foram igualmente susceptíveis à infecção se comparados aos animais selvagens. Ao contrário, a morte do macrófago resultou em liberação da bactéria para o meio extracelular tornando-a exposta à fagocitose e morte pelas espécies reativas de oxigênio presentes nos neutrófilos. Neste trabalho, foi demonstrado que somente a bactéria expressando flagelina, induz morte do macrófago dependente de NLRC4 in vivo, e esse fenômeno foi temporalmente relacionado com a remoção da bactéria. De acordo com isso, demonstramos no presente estudo que a infecção in vitro de macrófagos peritoneais por $S$. Typhimurium selvagem leva à morte das células infectadas, observada $6 \mathrm{~h}$ após a 
infecção. Entretanto, a bactéria mutante que perdeu a expressão da flagelina, não foi capaz de induzir morte do macrófago, confirmando o requerimento desse agonista para indução de morte celular. Ainda, nós demonstramos que macrófagos infectados por S. Typhimurium mutante, sem flagelina, possuíam maior carga bacteriana em comparação com os macrófagos infectados com a bactéria selvagem, sugerindo que na ausência desse agonista, a bactéria falha em induzir morte celular, tornando o macrófago susceptível à infecção. Juntos, esses dados corroboram com o envolvimento da piroptose no controle de patógenos intracelulares por macrófagos.

Entretanto, a regulação molecular da piroptose ainda é um campo bastante inexplorado. Sabe-se que, uma vez ativa, a caspase-1 promoverá a rápida formação de poros na membrana plasmática que culminarão em inchaço celular e posterior lise osmótica da célula que caracterizam o processo de piroptose. Além disso, a caspase-1 também é responsável pela clivagem do DNA observada durante a piroptose que apresenta um padrão distinto daquela observada durante a morte apoptótica (Fink e Cookson, 2005; Bergsbaken et al., 2009). Entretanto, ainda permanecem desconhecidos os alvos moleculares através dos quais a caspase-1 promove os eventos que culminarão na morte piroptótica da célula. Além disso, os mecanismos que promovem a ativação da caspase-1 após reconhecimento de agonistas pelos receptores presentes nos macrófagos ainda permanecem controversos. Uma vez que grande parte dos estudos aborda o papel desses receptores utilizando o microorganismo inteiro, pouco se conhece sobre o papel individual destes na ativação do macrófago e na indução do processo de morte celular.

A flagelina pode ser reconhecida tanto pelo receptor transmembrânico TLR5 quanto pelos inflamassomas NLRC4 e NAIP5 (Iwasaki e Medzhitov, 2004; Franchi et al., 2006; Molofsky et al., 2006; Ren et al., 2006; Lightfield et al., 2008), fato que torna o uso desse agonista uma excelente ferramenta experimental para investigar de maneira particular as consequências do reconhecimento de receptores transmembrâncios e citosólicos na ativação dos macrófagos e na indução do processo de morte celular, a partir do reconhecimento de um agonista único, eliminando a influência de qualquer contaminante proveniente do uso da bactéria inteira. Alguns estudos que realizaram esta abordagem demonstraram que a 
presença das flagelinas de $S$. typhimurium e L. pneumophila no citosol, na ausência de infecção pela bactéria, leva à ativação de caspase-1 e tem efeito tóxico em macrófagos, de maneira dependente dos inflamassomas NLRC4 e NAIP5 (Lightfield et al., 2008). De acordo com isso, nós demonstramos que a introdução da flagelina purificada de $B$. subtilis e $S$. typhimurium diretamente no citosol celular é suficiente para induzir liberação de IL-1 $\beta$ dependente de caspase-1, e levar macrófagos peritoneais à morte, de maneira dose-dependente. Em contrapartida, a estimulação pelos agonistas em sua forma livre induziu liberação da citocina IL-6, condizente com o seu reconhecimento extracelular pelo receptor TLR5, sugerindo que o macrófago responde de maneira distinta à ativação de receptores transmembrânicos e citosólicos.

Entretanto, ao contrário da flagelina de $B$. subitlis, a flagelina de $S$. typhimurium, quando administrada em sua forma livre, foi capaz de ativar caspase-1 no citosol celular, levando à liberação de IL-1 $\beta$ e de LDH pelos macrófagos estimulados. De acordo com isso, recentemente foi demonstrado que a linhagem de macrófagos J774A.1 produz IL-1 $\beta$ e IL-18 em resposta à flagelina purificada de $S$. typhimurium em sua forma livre (Vijay-Kumar et al., 2010). Neste estudo, a flagelina livre foi capaz de induzir clivagem de caspase-1, observada por western blotting e a liberação de IL-1 $\beta$ foi bloqueada com a adição de z-YVAD-fmk, inibidor específico da caspase-1. Além disso, a flagelina pôde ser facilmente detectada em lisados celulares das células J774A.1 através da técnica de immunoblotting, e também por microscopia confocal, revelando a presença da flagelina bacteriana no citosol celular. De fato, nossos dados também demonstram que a produção de IL-1 $\beta$ induzida pela flagelina de $S$. typhimurium em sua forma livre é totalmente dependente da atividade de caspase-1, uma vez que sua produção é abolida nas células provenientes de animais deficientes nesta molécula e no inflamassoma NLRC4. Esses dados sugerem que a flagelina de $S$. typhimurium, e não a flagelina de $B$. subtilis, possui a habilidade de alcançar o citosol celular e ativar caspase-1. Entretanto, o mecanismo através do qual a flagelina livre de $S$. typhimurium penetra no citosol celular ainda permanece desconhecido.

O reconhecimento da flagelina pelo TLR5 requer aminoácidos localizados na região D1 da flagelina (e.g., isoleucine 411) (Smith et al., 2003). Em contrapartida, 
uma sequência de 35 aminoácidos localizada no domínio D0 na porção C-terminal da flagelina é a responsável pelo reconhecimento deste agonista pelos receptores citosólicos NLRC4 e NAIP5 (Lightfield et al., 2008). Esta região da estrutura da flagelina é fundamental para a montagem do flagelo e se mantém altamente conservada para diferentes espécies bacterianas. Embora ambas flagelinas de $S$. typhimurium e $B$. subtilis possuam essas porções conservadas, nós observamos que a flagelina de $S$. typhimurium induz níveis muito mais elevados de IL-6 e de IL-1 $\beta$ do que a flagelina de $B$. subtilis quando administradas na mesma concentração molar, em sua forma livre e citosólica, respectivamente. Esses dados sugerem que, apesar de ambas possuírem essas regiões conservadas fundamentais para 0 reconhecimento pelos receptores TLR5 e NLRC4, as flagelinas modulam de maneira distinta a ativação do macrófago. Uma possibilidade é de que outros domínios da molécula da flagelina de $S$. typhimurium que possui aproximadamente o dobro da sequência de aminoácidos da flagelina de B. subtilis (Fig. 4), possam ser reconhecidos por outros receptores presentes nos macrófagos, promovendo um efeito sinérgico na resposta à flagelina de $S$. typhimurium.

O fato da flagelina de livre de $B$. subtilis não alcançar o citosol celular a torna uma excelente ferramenta para o estudo exclusivo do papel dos inflamassomas na ativação e morte de macrófagos induzidos pela flagelina. De fato, nós demonstramos que a flagelina de $B$. subtilis quando introduzida diretamente no citosol celular, por meio das vesículas lipídicas DOTAP, induz morte celular por uma via de ativação independente da molécula adaptadora MyD88, o que condiz com a exclusão do TLR5 nesse processo. Isso está de acordo com dados da literatura que demonstraram ativação de caspase-1, citotoxicidade e liberação de IL-1ß em macrófagos derivados da medula óssea de animais deficientes em TLR5, durante a infecção por S. typhimurium (Miao et al., 2006). Ainda, nossos dados com os macrófagos deficientes de MyD88 podem ser considerados um excelente controle da nossa ferramenta experimental, pois descarta qualquer possibilidade de que o processo de morte por nós observado possa estar sendo influenciado pela ativação do TLR5 em resposta ao reconhecimento de resquícios do agonista livre durante a preparação da flagelina inserida no DOTAP (FLA-B.S. Dot). 
A piroptose é acompanhada da liberação das citocinas IL-1 $\beta$ e IL-18, que só se tornam moléculas biologicamente ativas após clivagem pela caspase-1 (Raupach et al., 2006). Estas são citocinas multifuncionais que desempenham papéis centrais na inflamação aguda e crônica e potencialmente estimulam febre, recrutamento de células imunes, aumento da função de células $T$ e NK, e produção de diversas citocinas secundárias. Por possuírem papéis tão relevantes na resposta imune do hospedeiro frente a diversas infecções, e serem liberadas no contexto de ativação de inflamassomas e caspase-1 que leva posteriormente à morte do macrófago infectado, fomos investigar se essas citocinas, por si só, não poderiam atuar de maneira autócrina e parácrina, na indução de morte celular. A adição das citocinas recombinantes IL-1 $\beta$, IL-18 ou ambas na cultura de macrófagos não foi capaz de induzir a morte celular, mesmo quando presentes em quantidades bem superiores àquelas liberadas em resposta à flagelina citosólica. Além disso, a ocorrência de morte celular em macrófagos deficientes na molécula adaptadora MyD88, também é um indício de que as citocinas IL-1 $1 \beta$ e IL-18 não atuam no processo de morte celular, uma vez que seus receptores se utilizam desta molécula para transduzir sinais intracelulares e realizar suas funções (Medzhitov et al., 1998). Esses dados concordam com um estudo que mostra que nenhuma citocina é requerida para a indução de morte do macrófago durante infecção por S. typhimurium (Monack et al., 2001). Utilizando macrófagos derivados da medula óssea de camundongos deficientes em IL-1 $\beta$ tratados com anticorpos neutralizantes para IL-18, foi observado que, embora ambas as citocinas sejam liberadas durante a piroptose, a ausência delas não impede a morte do macrófago. Assim, a morte celular e a liberação de IL-1 $\beta$ induzida por flagelina são fenômenos concomitantes, mas parecem realizar funções independentes que, juntas, contribuem para o resultado pró-inflamatório observado durante a piroptose.

Embora seja bem descrito que a liberação das citocinas IL-1 $\beta$ e IL-18 para o meio extracelular ocorra concomitantemente ao processo de piroptose, o exato mecanismo de secreção dessas citocinas ainda permanece controverso. Silveira e Zamboni (2010) demonstraram que a formação de poros na membrana de células infectadas por $L$. pneumophila é um processo altamente regulado que requer ativação de caspase-1 e NLRC4 e que é desencadeada em resposta a bactérias expressando flagelina e sistema de secreção funcional. Este processo foi 
temporalmente associado à liberação de IL $1 \beta$ e precede o fênomeno de lise celular e piroptose. De acordo com isso, nós também demonstramos que somente a flagelina citosólica de $B$. subitlis, e não seu reconhecimento extracelular foi capaz de induzir a formação de poros na membrana plasmática, $1 \mathrm{~h}$ após a adição do estímulo. Sendo assim, é possível que os poros formados precocemente após estimulação por flagelina citosólica de $B$. subtilis contribuam diretamente para promover inchaço celular, culminando em lise osmótica das células, como vem sendo descrito na literatura. Entretanto, nossos resultados sugerem que o fenômeno de formação de poros ocorre muito precocemente e não está temporalmente vinculado à liberação de IL-1 $\beta$, durante estimulação por flagelina citosólica de B.subtilis. Ao contrário, conseguimos detectar quantidades significativas de IL1 $\beta$ após $3 \mathrm{~h}$ de estímulo, quando já não se observava mais a formação de poros. Neste tempo, as células estimuladas já haviam entrado em processo de lise celular, observado pela liberação de LDH para o meio extracelular, sugerindo que a IL1 $\beta$ é liberada em quantidades significativas somente durante $o$ processo de lise celular. Esses dados são divergentes daqueles obtidos durante a infecção de macrófagos com L. pneumophila (Silveira e Zamboni, 2010) e S. typhimurium (Fink e Cookson, 2006), nas quais a secreção de IL-1 $\beta$ parece ocorrer antes da lise celular. Assim, é possível que durante a infecção pela bactéria inteira haja a interferência de outros agonistas no processo de liberação de IL-1 $\beta$ que podem induzir outros mecanismos de secreção já sugeridos, como exocitose lisossomal e extravasamento de microvesículas (MacKenzie et al., 2001; Andrei et al., 2004).

Apesar de ser bem descrito na literatura que a morte celular induzida após reconhecimento da flagelina bacteriana no citosol celular é um fenômeno exclusivamente dependente da atividade da caspase-1 após engajamento pelos inflamassomas, nós observamos que as células provenientes de animais knockouts para o inflamassoma NLRC4 e para a caspase-1 sofrem morte celular após estímulo por flagelina citosólica, embora com cinética atrasada em comparação às células provenientes dos animais selvagens. Quanto aos macrófagos dos animais knockouts para NLRC4, esses apresentaram, no tempo de $6 \mathrm{~h}$ de estímulo, menor frequência de morte celular em relação às células deficientes em caspase-1 e selvagens, porém, após $24 \mathrm{~h}$ elas alcançaram níveis semelhantes, como observado pelo ensaio de MTT. O sensor citosólico que pode ser responsável pela indução de 
morte celular por flagelina na ausência de NLRC4 permanece sendo um mistério. Sabe-se que o inflamassoma NLRP3, uma vez ativado, promove morte celular pironecrótica com características semelhantes à morte piroptótica induzida por NLRC4 (Willingham et al., 2007; Willingham et al., 2009). Entretanto, apesar de ser um sensor para uma grande variedade de estímulos, não há evidências de que este receptor responda à flagelina no citosol celular. Recentemente, foi demonstrado que ambos, NLRC4 e NLRP3 possuem papéis redundantes durante infecção por $S$. typhimurium, porém respondem a estímulos distintos. Enquanto o NLRC4 ativa caspase-1 de maneira dependente do sistema de secreção e da flagelina bacteriana, o inflamassoma NLRP3 exerce sua função de maneira independente da flagelina, após reconhecimento de estímulo ainda desconhecido (Broz et al., 2010).

Neste contexto, um possível papel para o receptor NAIP5 pode ser sugerido, uma vez que o mesmo também reconhece flagelina citosólica (Lightfield et al., 2008). Entretanto, os mecanismos que levam à ativação deste receptor e suas funções, são eventos bem pouco elucidados. Macrófagos deficientes em NAIP5 possuem ativação de caspase-1 defeituosa, porém, ao invés de possuir um domínio amino-terminal do tipo CARD ou PYD, o NAIP5 possui um domínio do tipo BIR, que parece ser incapaz de recrutar a proteína adaptadora ASC ou a protease caspase-1. Dessa maneira, tem sido proposto que a ativação de caspase-1 mediada por NAIP5 é um reflexo da sua interação com o NLRC4 (Zamboni et al., 2006). Entretanto, o NAIP5 não compartilha com o NLRC4 todas as funções mediadas pela caspase-1 (Lightfield et al., 2011). Dessa maneira, a possibilidade da interação entre NAIP5 e outras moléculas que culmine em eventos ainda desconhecidos não pode ser descartada. Entretanto, muito ainda tem que ser explorado nessa área, tendo em vista que nenhum estudo demonstrou, até o presente momento, uma ligação estrutural direta entre os receptores do tipo NOD e os seus agonistas, incluindo o receptor NAIP5 e a flagelina.

A ativação de caspase-1 após engajamento dos inflamassomas vem sendo descrito como o principal evento que controla a morte piroptótica, pois esta protease é a responsável por gerar fundamentalmente todos os aspectos da piroptose (Bergsbaken et al., 2009). Surpreendentemente, ao contrário do que prevê a literatura atual, nós observamos que as células deficientes em caspase-1 
estimuladas com flagelina citosólica também sofrem processo de lise celular tempodependente em uma cinética mais lenta que àquela observada para os animais selvagens. Porém, durante nosso ensaio de formação de poros não detectamos um momento onde houvesse a presença de poros nas células dos animais deficientes em caspase-1, deixando em aberto se a morte nessas células é um fenômeno decorrente da formação de poros independentes de caspase-1 na membrana plasmática, ou se a lise celular observada ocorre como conseqüência de outro mecanismo. Fenômeno semelhante também é observado na morte celular induzida por estímulos apoptogênicos na ausência das caspases executoras desse processo, como caspase-3, 6, 9 (Pereira e Amarante-Mendes, 2011). As alterações bioquímicas e morfológicas associadas com a apoptose como clivagem de DNA em regiões oligonucleossomais, perda de volume celular, exposição de fosfatidil serina, formação de pregas na membrana celular e geração de corpos apóptóticos são eventos dependentes da ativação das caspases 3, 6 e 9 (Taylor et al., 2008; Pop e Salvesen, 2009). No entanto, alguns trabalhos vêm demonstrando que, na maioria dos modelos experimentais, bem como em algumas situações fisiológicas em que a ativação das caspases e, portanto, a apoptose, é impedida de ocorrer, isso não resulta em aumento da sobrevida celular e clonogenicidade (Xiang et al., 1996; McCarthy et al., 1997; Amarante-Mendes et al., 1998). Em vez disso, em tais condições, as células simplesmente passam por outra forma de morte celular, sugerindo que a opção tomada pela célula é regida independentemente da ativação da maquinaria apoptótica e indicando que a apoptose pode não ser um processo de morte celular, mas simplesmente uma etapa terminal de empacotamento celular, responsável pela destinação adequada das células que já estão comprometidas com a morte. Da mesma maneira, de acordo com nossos resultados, a piroptose pode ser um fenômeno responsável por imprimir determinadas características orquestradas pela atividade da caspase-1, como a liberação de IL-1 $\beta$ e a formação precoce de poros na membrana celular, nas células que já estão destinadas a morrer, e não um processo de morte celular, propriamente dito.

Nossos resultados contribuem para o melhor entendimento dos mecanismos moleculares que coordenam os processos de ativação e morte do macrófago em resposta à flagelina. No entanto, os mesmos dados abrem outras importantes questões a serem elucidadas, como o entendimento dos mecanismos que culminam 
na morte do macrófago em resposta à ativação dos inflamassomas, assim como a maquinaria envolvida em sua regulação. Ainda, uma vez que a morte celular acontece na ausência da caspase-1, a susceptilidade a infecções bacterianas observadas nos animais deficientes nessa protease, pode ser resultado de outros fenômenos ainda desconhecidos e não apenas da manutenção do nicho para replicação dos microorganismos, como postulado até o momento (Miao et al., 2010). 
6 CONCLUSÃO 
* Salmonella typhimurium selvagem expressando flagelina induz morte dos macrófagos.

* Macrófagos são mais permissivos à replicação de Salmonella typhimurium mutante sem flagelina.

* Somente flagelina citosólica de $B$. subtilis induz liberação de IL-1 $\beta$, formação de poros na membrana celular e morte do macrófago;

* A flagelina livre de $S$. typhimurium induz maior produção de IL-6 por macrófagos em comparação com a flagelina livre de $B$. subtilis.

* A flagelina citosólica de $S$. typhimurium induz maior produção de IL-1 por macrófagos em comparação com a flagelina citosólica de $B$. subtilis.

* Flagelina livre de $S$. typhimurium e não de B. subtilis, possui habilidade de alcançar o citosol celular e induzir liberação de IL-1 $\beta$ e LDH.

* A molécula adaptadora Myd88 e as citocinas IL-1ß e IL-18 não estão envolvidas com a morte celular.

* A produção de IL-1 e lise celular de macrófagos em resposta à flagelina citosólica são eventos subseqüentes à formação de poros na membrana celular.

* A produção de IL-1 por macrófagos em resposta à flagelina citosólica acontece de maneira dependente de caspase-1.

- As flagelinas citosólicas de B. subtilis e $S$. typhimurium induzem a lise dos macrófagos na ausência de caspase-1. 


\section{REFERÊNCIAS}




\section{REFERÊNCIAS*}

Amarante-Mendes GP, Finucane DM, Martin SJ, Cotter TG, Salvesen GS, Green DR. Antiapoptotic oncogenes prevent caspase-dependent and independent commitment for cell death. Cell Death Differ. 1998;5(4):298-306.

Amer A, Franchi L, Kanneganti TD, Body-Malapel M, Ozoren N, Brady G, Meshinchi S, Jagirdar R, Gewirtz A, Akira S, Nunez G. Regulation of Legionella phagosome maturation and infection through flagellin and host Ipaf. J Biol Chem. 2006;281(46):35217-23.

Andrei C, Margiocco P, Poggi A, Lotti LV, Torrisi MR, Rubartelli A. Phospholipases C and A2 control lysosome-mediated IL-1 beta secretion: Implications for inflammatory processes. Proc Natl Acad Sci U S A. 2004;101(26):9745-50.

Bergsbaken T, Cookson BT. Macrophage activation redirects yersinia-infected host cell death from apoptosis to caspase-1-dependent pyroptosis. PLoS Pathog. 2007;3(11):e161.

Bergsbaken T, Fink SL, Cookson BT. Pyroptosis: host cell death and inflammation. Nat Rev Microbiol. 2009;7(2):99-109.

Bortoluci KR, Medzhitov R. Control of infection by pyroptosis and autophagy: role of TLR and NLR. Cell Mol Life Sci. 2010.

Brennan MA, Cookson BT. Salmonella induces macrophage death by caspase-1-dependent necrosis. Mol Microbiol. 2000;38(1):31-40.

Broz P, Newton K, Lamkanfi M, Mariathasan S, Dixit VM, Monack DM. Redundant roles for inflammasome receptors NLRP3 and NLRC4 in host defense against Salmonella. J Exp Med. 2010;207(8):1745-55.

Buzzo CL, Campopiano JC, Massis LM, Lage SL, Cassado AA, Leme-Souza R, Dias da Cunha L, Russo M, Zamboni DS, Amarante-Mendes GP, Bortoluci KR. A novel pathway for inducible nitric oxide synthase (iNOS) activation through inflammasomes. J Biol Chem. 2010.

Carty M, Goodbody R, Schroder M, Stack J, Moynagh PN, Bowie AG. The human adaptor SARM negatively regulates adaptor protein TRIF-dependent Toll-like receptor signaling. Nat Immunol. 2006;7(10):1074-81. 
Chen LM, Kaniga K, Galan JE. Salmonella spp. are cytotoxic for cultured macrophages. Mol Microbiol. 1996a;21(5):1101-15.

Chen Y, Smith MR, Thirumalai K, Zychlinsky A. A bacterial invasin induces macrophage apoptosis by binding directly to ICE. EMBO J. 1996b;15(15):3853-60.

Delaleu N, Bickel M. Interleukin-1 beta and interleukin-18: regulation and activity in local inflammation. Periodontol 2000. 2004;35:42-52.

Fantuzzi G, Dinarello CA. Interleukin-18 and interleukin-1 beta: two cytokine substrates for ICE (caspase-1). J Clin Immunol. 1999;19(1):1-11.

Faustin B, Lartigue L, Bruey JM, Luciano F, Sergienko E, Bailly-Maitre B, Volkmann N, Hanein D, Rouiller I, Reed JC. Reconstituted NALP1 inflammasome reveals two-step mechanism of caspase-1 activation. Mol Cell. 2007;25(5):713-24.

Fink SL, Cookson BT. Apoptosis, pyroptosis, and necrosis: mechanistic description of dead and dying eukaryotic cells. Infect Immun. 2005;73(4):1907-16.

Fink SL, Cookson BT. Caspase-1-dependent pore formation during pyroptosis leads to osmotic lysis of infected host macrophages. Cell Microbiol. 2006;8(11):1812-25.

Fink SL, Cookson BT. Pyroptosis and host cell death responses during Salmonella infection. Cell Microbiol. 2007;9(11):2562-70.

Fotakis G, Timbrell JA. In vitro cytotoxicity assays: comparison of LDH, neutral red, MTT and protein assay in hepatoma cell lines following exposure to cadmium chloride. Toxicol Lett. 2006;160(2):171-7.

Franchi L, Amer A, Body-Malapel M, Kanneganti TD, Ozoren N, Jagirdar R, Inohara N, Vandenabeele P, Bertin J, Coyle A, Grant EP, Nunez G. Cytosolic flagellin requires Ipaf for activation of caspase-1 and interleukin 1beta in salmonella-infected macrophages. Nat Immunol. 2006;7(6):576-82.

Franchi L, Stoolman J, Kanneganti TD, Verma A, Ramphal R, Nunez G. Critical role for Ipaf in Pseudomonas aeruginosa-induced caspase-1 activation. Eur $\mathrm{J}$ Immunol. 2007;37(11):3030-9.

Gay NJ, Keith FJ. Drosophila Toll and IL-1 receptor. Nature. 1991;351(6325):355-6. 
Hayashi F, Smith KD, Ozinsky A, Hawn TR, Yi EC, Goodlett DR, Eng JK, Akira S, Underhill DM, Aderem A. The innate immune response to bacterial flagellin is mediated by Toll-like receptor 5. Nature. 2001;410(6832):1099-103.

Henry T, Monack DM. Activation of the inflammasome upon Francisella tularensis infection: interplay of innate immune pathways and virulence factors. Cell Microbiol. 2007;9(11):2543-51.

Holscher C, Kohler G, Muller U, Mossmann H, Schaub GA, Brombacher F. Defective nitric oxide effector functions lead to extreme susceptibility of Trypanosoma cruzi-infected mice deficient in gamma interferon receptor or inducible nitric oxide synthase. Infect Immun. 1998;66(3):1208-15.

Inohara N, Nunez G. NODs: intracellular proteins involved in inflammation and apoptosis. Nat Rev Immunol. 2003;3(5):371-82.

Iwasaki A, Medzhitov R. Toll-like receptor control of the adaptive immune responses. Nat Immunol. 2004;5(10):987-95.

Kabelitz D, Medzhitov R. Innate immunity--cross-talk with adaptive immunity through pattern recognition receptors and cytokines. Curr Opin Immunol. 2007;19(1):1-3.

Kawai T, Akira S. TLR signaling. Semin Immunol. 2007;19(1):24-32.

Kopp E, Medzhitov R. Recognition of microbial infection by Toll-like receptors. Curr Opin Immunol. 2003;15(4):396-401.

Kuida K, Lippke JA, Ku G, Harding MW, Livingston DJ, Su MS, Flavell RA. Altered cytokine export and apoptosis in mice deficient in interleukin-1 beta converting enzyme. Science. 1995;267(5206):2000-3.

Lara-Tejero M, Sutterwala FS, Ogura Y, Grant EP, Bertin J, Coyle AJ, Flavell RA, Galan JE. Role of the caspase-1 inflammasome in Salmonella typhimurium pathogenesis. J Exp Med. 2006;203(6):1407-12.

Li P, Allen H, Banerjee S, Franklin S, Herzog L, Johnston C, McDowell J, Paskind M, Rodman L, Salfeld J, et al. Mice deficient in IL-1 beta-converting enzyme are defective in production of mature IL-1 beta and resistant to endotoxic shock. Cell. 1995;80(3):401-11.

Lightfield KL, Persson J, Brubaker SW, Witte CE, von Moltke J, Dunipace EA, Henry T, Sun YH, Cado D, Dietrich WF, Monack DM, Tsolis RM, Vance RE. Critical function for Naip5 in 
inflammasome activation by a conserved carboxy-terminal domain of flagellin. Nat Immunol. 2008;9(10):1171-8.

Lightfield KL, Persson J, Trinidad NJ, Brubaker SW, Kofoed EM, Sauer JD, Dunipace EA, Warren SE, Miao EA, Vance RE. Differential Requirements for NAIP5 in Activation of the NLRC4 Inflammasome. Infect Immun. 2011;79(4):1606-14.

Lundberg U, Vinatzer U, Berdnik D, von Gabain A, Baccarini M. Growth phase-regulated induction of Salmonella-induced macrophage apoptosis correlates with transient expression of SPI-1 genes. J Bacteriol. 1999;181(11):3433-7.

MacKenzie A, Wilson HL, Kiss-Toth E, Dower SK, North RA, Surprenant A. Rapid secretion of interleukin-1beta by microvesicle shedding. Immunity. 2001;15(5):825-35.

Mariathasan S, Newton K, Monack DM, Vucic D, French DM, Lee WP, Roose-Girma M, Erickson S, Dixit VM. Differential activation of the inflammasome by caspase-1 adaptors ASC and Ipaf. Nature. 2004;430(6996):213-8.

Martinon F, Burns K, Tschopp J. The inflammasome: a molecular platform triggering activation of inflammatory caspases and processing of proIL-beta. Mol Cell. 2002;10(2):41726.

Martinon F, Gaide O, Petrilli V, Mayor A, Tschopp J. NALP inflammasomes: a central role in innate immunity. Semin Immunopathol. 2007;29(3):213-29.

Martinon F, Tschopp J. Inflammatory caspases and inflammasomes: master switches of inflammation. Cell Death Differ. 2007;14(1):10-22.

McCarthy NJ, Whyte MK, Gilbert CS, Evan GI. Inhibition of Ced-3/ICE-related proteases does not prevent cell death induced by oncogenes, DNA damage, or the Bcl-2 homologue Bak. J Cell Biol. 1997;136(1):215-27.

McGahon AJ, Martin SJ, Bissonnette RP, Mahboubi A, Shi Y, Mogil RJ, Nishioka WK, Green DR. The end of the (cell) line: methods for the study of apoptosis in vitro. Methods Cell Biol. 1995;46:153-85.

Medzhitov R, Preston-Hurlburt P, Kopp E, Stadlen A, Chen C, Ghosh S, Janeway CA, Jr. MyD88 is an adaptor protein in the hToll/IL-1 receptor family signaling pathways. Mol Cell. 1998;2(2):253-8. 
Miao EA, Alpuche-Aranda CM, Dors M, Clark AE, Bader MW, Miller SI, Aderem A. Cytoplasmic flagellin activates caspase-1 and secretion of interleukin 1beta via Ipaf. Nat Immunol. 2006;7(6):569-75.

Miao EA, Leaf IA, Treuting PM, Mao DP, Dors M, Sarkar A, Warren SE, Wewers MD, Aderem A. Caspase-1-induced pyroptosis is an innate immune effector mechanism against intracellular bacteria. Nat Immunol. 2010;11(12):1136-42.

Molofsky AB, Byrne BG, Whitfield NN, Madigan CA, Fuse ET, Tateda K, Swanson MS. Cytosolic recognition of flagellin by mouse macrophages restricts Legionella pneumophila infection. J Exp Med. 2006;203(4):1093-104.

Monack DM, Detweiler CS, Falkow S. Salmonella pathogenicity island 2-dependent macrophage death is mediated in part by the host cysteine protease caspase-1. Cell Microbiol. 2001;3(12):825-37.

Nakanishi K, Yoshimoto T, Tsutsui H, Okamura H. Interleukin-18 regulates both Th1 and Th2 responses. Annu Rev Immunol. 2001;19:423-74.

Nicholson DW. Caspase structure, proteolytic substrates, and function during apoptotic cell death. Cell Death Differ. 1999;6(11):1028-42.

Pereira WO, Amarante-Mendes GP. Apoptosis: a program of cell death or cell disposal? Scand J Immunol. 2011.

Pop C, Salvesen GS. Human caspases: activation, specificity, and regulation. J Biol Chem. 2009;284(33):21777-81.

Poyet JL, Srinivasula SM, Tnani M, Razmara M, Fernandes-Alnemri T, Alnemri ES. Identification of Ipaf, a human caspase-1-activating protein related to Apaf-1. J Biol Chem. 2001;276(30):28309-13.

Raupach B, Peuschel SK, Monack DM, Zychlinsky A. Caspase-1-mediated activation of interleukin-1beta (IL-1beta) and IL-18 contributes to innate immune defenses against Salmonella enterica serovar Typhimurium infection. Infect Immun. 2006;74(8):4922-6.

Ren T, Zamboni DS, Roy CR, Dietrich WF, Vance RE. Flagellin-deficient Legionella mutants evade caspase-1- and Naip5-mediated macrophage immunity. PLoS Pathog. 2006;2(3):e18. 
Sansonetti PJ, Phalipon A, Arondel J, Thirumalai K, Banerjee S, Akira S, Takeda K, Zychlinsky A. Caspase-1 activation of IL-1beta and IL-18 are essential for Shigella flexneriinduced inflammation. Immunity. 2000;12(5):581-90.

Schappi MG, Jaquet V, Belli DC, Krause KH. Hyperinflammation in chronic granulomatous disease and anti-inflammatory role of the phagocyte NADPH oxidase. Semin Immunopathol. 2008;30(3):255-71.

Silveira TN, Zamboni DS. Pore formation triggered by Legionella spp. is an Nlrc4 inflammasome-dependent host cell response that precedes pyroptosis. Infect Immun. 2010;78(3):1403-13.

Smith KD, Andersen-Nissen E, Hayashi F, Strobe K, Bergman MA, Barrett SL, Cookson BT, Aderem A. Toll-like receptor 5 recognizes a conserved site on flagellin required for protofilament formation and bacterial motility. Nat Immunol. 2003;4(12):1247-53.

Stasia MJ, Cathebras P, Lutz MF, Durieu I. [Chronic-granulomatous disease.]. Rev Med Interne. 2009;30(3):221-32.

Suzuki T, Franchi L, Toma C, Ashida H, Ogawa M, Yoshikawa Y, Mimuro H, Inohara N, Sasakawa C, Nunez G. Differential regulation of caspase-1 activation, pyroptosis, and autophagy via Ipaf and ASC in Shigella-infected macrophages. PLoS Pathog. 2007;3(8):e111.

Taylor RC, Cullen SP, Martin SJ. Apoptosis: controlled demolition at the cellular level. Nat Rev Mol Cell Biol. 2008;9(3):231-41.

Ting JP, Willingham SB, Bergstralh DT. NLRs at the intersection of cell death and immunity. Nat Rev Immunol. 2008;8(5):372-9.

Vijay-Kumar M, Carvalho FA, Aitken JD, Fifadara NH, Gewirtz AT. TLR5 or NLRC4 is necessary and sufficient for promotion of humoral immunity by flagellin. Eur $\mathrm{J}$ Immunol. 2010;40(12):3528-34.

Willingham SB, Allen IC, Bergstralh DT, Brickey WJ, Huang MT, Taxman DJ, Duncan JA, Ting JP. NLRP3 (NALP3, Cryopyrin) facilitates in vivo caspase-1 activation, necrosis, and HMGB1 release via inflammasome-dependent and -independent pathways. J Immunol. 2009;183(3):2008-15.

Willingham SB, Bergstralh DT, O'Connor W, Morrison AC, Taxman DJ, Duncan JA, Barnoy S, Venkatesan MM, Flavell RA, Deshmukh M, Hoffman HM, Ting JP. Microbial pathogen- 
induced necrotic cell death mediated by the inflammasome components CIAS1/cryopyrin/NLRP3 and ASC. Cell Host Microbe. 2007;2(3):147-59.

Xiang J, Chao DT, Korsmeyer SJ. BAX-induced cell death may not require interleukin 1 betaconverting enzyme-like proteases. Proc Natl Acad Sci U S A. 1996;93(25):14559-63.

Yamamoto M, Akira S. [TIR domain--containing adaptors regulate TLR-mediated signaling pathways]. Nippon Rinsho. 2004;62(12):2197-203.

Zamboni DS, Kobayashi KS, Kohlsdorf T, Ogura Y, Long EM, Vance RE, Kuida K, Mariathasan S, Dixit VM, Flavell RA, Dietrich WF, Roy CR. The Bircle cytosolic patternrecognition receptor contributes to the detection and control of Legionella pneumophila infection. Nat Immunol. 2006;7(3):318-25.

Zuckman DM, Hung JB, Roy CR. Pore-forming activity is not sufficient for Legionella pneumophila phagosome trafficking and intracellular growth. Mol Microbiol. 1999;32(5):990-1001. 